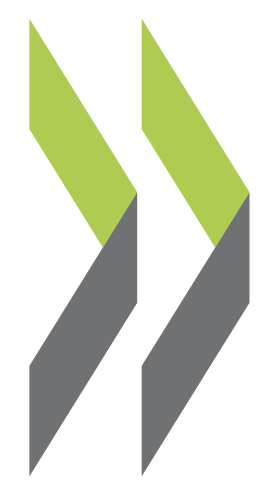

OECD Science, Technology and Industry Working Papers $2002 / 14$

\title{
Organisational Change and Firm Performance
}

\section{Marian Murphy}


Organisation de Coopération et de Développement Economiques

DIRECTORATE FOR SCIENCE, TECHNOLOGY AND INDUSTRY

STI Working Paper 2002/14

\section{INDUSTRY ISSUES}

ORGANISATIONAL CHANGE AND FIRM PERFORMANCE

Marian Murphy 


\section{STI Working Paper Series}

The Working Paper series of the OECD Directorate for Science, Technology and Industry is designed to make available to a wider readership selected studies prepared by staff in the Directorate or by outside consultants working on OECD projects. The papers included in the series cover a broad range of issues, of both a technical and policy-analytical nature, in the areas of work of the DSTI. The Working Papers are generally available only in their original language - English or French - with a summary in the other.

Comment on the papers is invited, and should be sent to the Directorate for Science, Technology and Industry, OECD, 2 rue André Pascal, 75775 Paris Cedex 16, France.

The opinions expressed in these papers are the sole responsibility of the author(s) and do not necessarily reflect those of the OECD or of the governments of its Member countries.

\section{http://www.oecd.org/sti/}


DSTI/DOC(2002)14

\title{
ORGANISATIONAL CHANGE AND FIRM PERFORMANCE
}

\begin{abstract}
Marian Murphy
Organisational change encompasses production processes (quality management, lean production, business re-engineering), management approaches (teamwork, training, flexible work and compensation) and external relations (outsourcing, customer relations, networking). Performance improvements from organisational investments are greatest when production, management and consumer approaches are combined, and when these bundled practices are implemented in conjunction with information and communications technologies (ICT). One explanation for the "productivity" may be that organisational change is key to realising benefits from ICT, while ICT is essential to implementing organisational change, necessitating combined investments to raise productivity growth. The proportion of OECD firms that introduced organisational changes rose significantly in the 1990s and the incidence of organisational change has been highest in service sectors. Larger firms, particularly those exposed to international competition, are more likely to invest in ICT and organisational change than smaller firms. Organisational change programmes may fail in the absence of greater employee participation and decentralised management. Governments should ensure proper frameworks for labour/management relations and for the introduction of flexible work practices, including part-time work and incentive-based pay. Approaches are needed to enlist unions as partners in implementing new work practices. Governments can also take steps to inform firms and train managers on the implementation of organisational change.
\end{abstract}

\section{CHANGEMENT ORGANISATIONNEL ET PERFORMANCES DES ENTREPRISES}

\section{Marian Murphy}

Le changement organisationnel englobe les procédés de production (gestion de la qualité, production économe en ressources, reconfiguration de l'entreprise), les méthodes de gestion (travail en équipe, formation, travail et rémunération flexibles) et les relations extérieures (externalisation, relations avec la clientèle, constitution de réseaux). Les améliorations des performances découlant d'investissements à finalité organisationnelle sont les plus importantes lorsque les stratégies de production, de gestion et de relations avec le consommateur sont intégrées et mises en œuvre de pair avec les technologies de l'information et des communications (TIC). Le "paradoxe de la productivité" tient peut-être à ce que le changement organisationnel est essentiel pour concrétiser les avantages des TIC, alors que ces mêmes TIC sont indispensables pour mettre en œuvre le changement organisationnel, ce qui nécessite des investissements combinés pour accélérer l'accroissement de la productivité. La proportion d'entreprises des pays Membres de l'OCDE qui ont mis en œuvre des changements organisationnels a augmenté considérablement dans les années 90 , et l'ampleur du phénomène a été beaucoup plus grande dans les industries de services. Les grandes entreprises, en particulier celles qui sont exposées à la concurrence internationale, sont davantage enclines à investir dans les TIC et le changement organisationnel que les entreprises plus petites. Le changement organisationnel risque de ne pas donner les résultats escomptés s'il ne s'accompagne pas d'une plus grande participation du personnel et d'une décentralisation de la gestion. Les pouvoirs publics doivent veiller à mettre en place des conditions propices aux relations travailleursdirection et à l'adoption de pratiques de travail flexibles, notamment en ce qui concerne le travail à temps partiel et la rémunération à base de primes. Il faut élaborer des stratégies pour s'assurer le concours des syndicats, qui doivent être des partenaires dans la mise en œuvre de nouvelles pratiques de travail. Les pouvoirs publics peuvent également prendre des mesures pour informer les entreprises et favoriser la formation de l'encadrement pour la mise en œuvre du changement organisationnel. 
TABLE OF CONTENTS

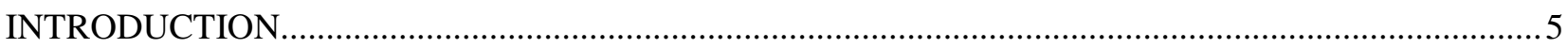

DRIVERS OF ORGANISATIONAL CHANGE

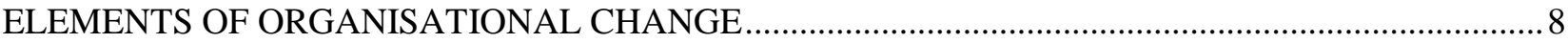

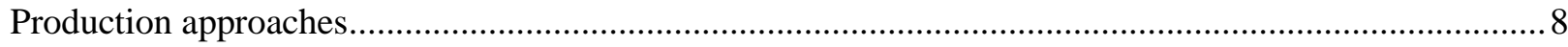

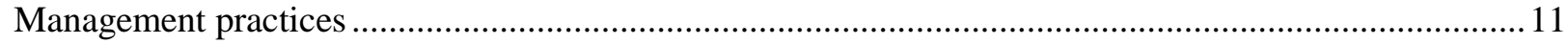

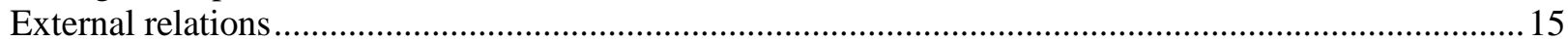

THE EFFECTS OF ORGANISATIONAL CHANGE ON FIRM PERFORMANCE ….............................. 18

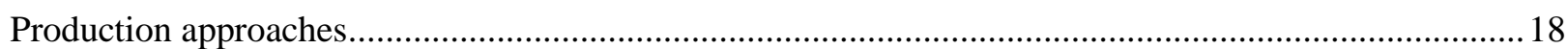

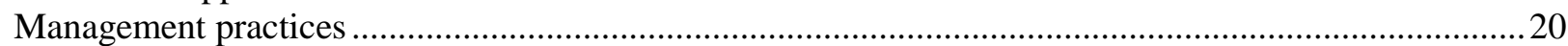

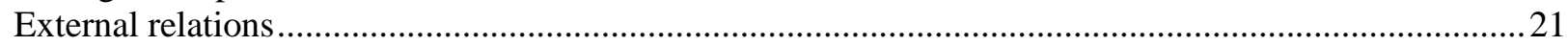

STRUCTURAL FACTORS AND ORGANISATIONAL CHANGE …....................................................2

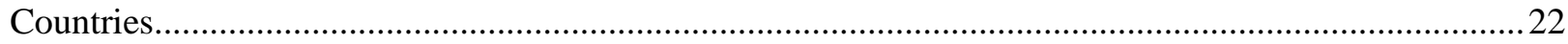

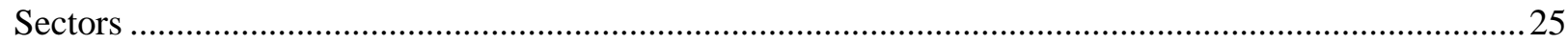

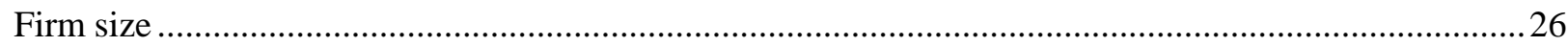

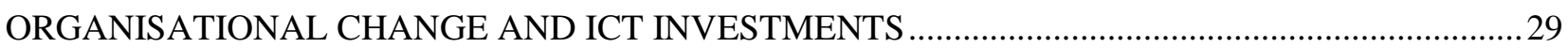

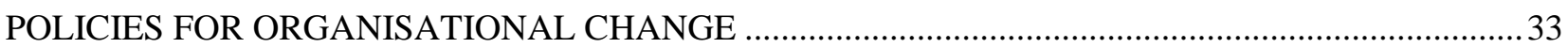

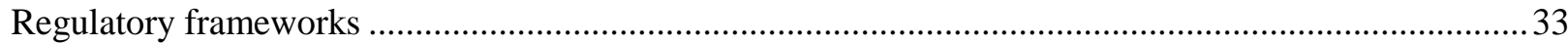

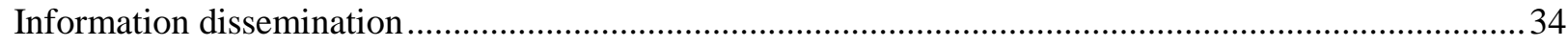

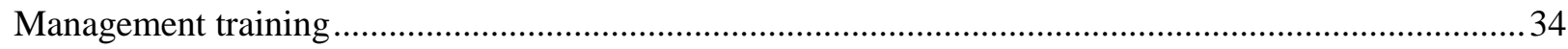

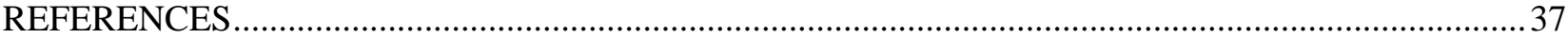


DSTI/DOC(2002)14

\section{INTRODUCTION}

OECD enterprises need to implement organisational changes to maximise benefits from new technology, particularly information and communications technology (ICT) and to realise productivity increases from investments in both tangible (plant, equipment) and intangible (research, training) assets. The extent of firm-level organisational change may be the difference between "old" and "new" economy performance. Organisational change refers to firm-level modifications of structures, work interactions and human resource practices, affecting both internal business processes as well as relationships with customers and other firms. In practice, the type of organisational changes selected and implemented by enterprises is influenced by factors at firm and sectoral level and by systemic, cultural and institutional variables at national level (OECD, 1998).

A rapidly integrating global economy, technological developments, and shifting consumer preferences are together resulting in intense competition between firms. Consequently, firms are forced to revise their strategies, structures and work practices in order to stay competitive. They are seeking ways to enhance the flexibility of their business processes as well as their responsiveness in relationships with clients and other firms. While in the past, organisational change was undertaken mostly by firms exposed to international competition, larger enterprises, and those in manufacturing, new work approaches are now being implemented across countries, sectors and firms of all sizes.

Organisational change is not new. Since the 1950s, many novel approaches to work organisation have emerged including the Japanese lean production models of the 1960-70s, the socio-technical approach associated with the Nordic countries, American human resource management techniques, the German consensus-based model involving work councils, and the collaborative network or cluster model exemplified by Italian firms at regional level. Other approaches include quality management and business re-engineering, while more recently emphasis has turned to managing customer relations and the knowledge base of firms.

Organisational change can vary in scope and intensity. It may be relatively superficial when restricted to the introduction of specific work practices or may be far reaching when radical work reorganisation is implemented that affects firm boundaries, e.g. through outsourcing and networking. Although it is difficult to measure organisational change or gauge its diffusion, empirical evidence on the incidence and effects of organisational change is growing. In spite of diversity in the implementation of organisational change and its intangible character, it is possible to identify recent trends as well as implications for firm performance. Evidence indicates that, in the absence of organisational change, enterprises may fail to realise the benefits of new technology, particularly ICT. This may be a partial explanation for the "productivity paradox" or the failure of many countries, sectors and firms to evidence productivity growth despite large investments in new technologies. 


\section{DRIVERS OF ORGANISATIONAL CHANGE}

The main driver of organisational change is the need for firms to adapt to changing competitive conditions. In the recent past, production and use of ICT have been linked to productivity growth in OECD countries $(O E C D, 2001 a)$. Something new is taking place in the structure of OECD economies and enterprises. However, to enhance performance in this "new economy," a number of organisational changes are needed at firm level (Table 1). Reasons for implementing changes to firm structures and organisation are to improve functioning in a changed business environment, to realise benefits from intangible investments, to respond to new demands from suppliers and customers, and to use effectively new technologies.

Table 1. Keys to the old and new economies

\begin{tabular}{lll}
\hline ISSUE & OLD ECONOMY & NEW ECONOMY \\
& & \\
Organisational form & Hierarchical, bureaucratic & Flat, team-based \\
Organisation of production & Mass production & Flexible production \\
Key drivers of growth & Capital/labour & Innovation/knowledge \\
Key technology driver & Mechanisation & Digitisation \\
Source of comparative advantage & Economies of scale & Innovation, quality, time-to-market \\
Relations with other firms & Go it alone & Alliances and collaboration \\
Workforce skills & Job-specific skills & Broad skills/cross-training \\
Labour/management relations & Adversarial & Collaborative
\end{tabular}

Source: Progressive Policy Institute (2000).

Organisational change is prompted by a firm's interrelated strategic objectives regarding productivity, profitability and market share. In survey findings, for example, increased efficiency emerges as one of the main motivators for organisational change in firms in Sweden, Finland, and Denmark. The longer-term strategic aim of enhanced performance was an important reason for organisational change in Sweden and Finland, while in Denmark, the need to improve work co-ordination within units, ahead of market pressures, and the need to maintain or improve market share were main drivers (Nutek, 1999). Market pressures were the overwhelming reason cited by Canadian firms for embarking on an organisational change programme (Table 2). Canadian firms also ranked meeting domestic and global competition and increased profitability as important (Magun, 1998).

Organisational change in enterprises is also being driven by the need to make better use of knowledge, technology and human resources in today's competitive environment. The increased importance of technology has been accompanied by an enhanced role for intangible assets, particularly innovative capacity and labour skills. Strategic business thinking has shifted away from products, plants and inventory towards employees, information and knowledge. Consequently there is far greater demand for multiskilling, upskilling and re-skilling of the labour force. Firms are adopting new "knowledge management" strategies which drive organisational change throughout the enterprise $(O E C D, 2001 b)$. 
DSTI/DOC(2002)14

Table 2. Reasons for restructuring in Canadian companies

(percentage of all respondents)

\begin{tabular}{lccc}
\hline \multicolumn{1}{c}{ Principal reasons } & Not important & Somewhat important & Very important \\
\hline Sustain or improve market share & 22.6 & 29.0 & 48.4 \\
Meet domestic competition & 24.2 & 30.6 & 45.2 \\
Meet global competition & 25.8 & 32.3 & 41.9 \\
Improve stock prices & 30.5 & 32.2 & 37.3 \\
Adopt new technologies & 45.2 & 29.0 & 25.8
\end{tabular}

Notes: Restructuring includes organisational change practices such as re-engineering, downsizing and total quality management programmes.

Source: Magun (1998).

As firm strategies become more geared to customers, new work practices are needed. Shorter product life cycles and a need to constantly renew products has caused firms to reorganise their businesses around the customer. The aim is to retain client loyalty and anticipate future market preferences. Previous models of mass production and standardised products are being supplanted by "mass customisation" as firms produce differentiated, high-quality goods, offering the customer almost unlimited choice. Whereas mass production aimed to minimise costs and maximise volume, mass customisation aims to deliver variety and differentiation through flexible and responsive production processes. This customer orientation must be built on far-reaching organisational changes in the enterprise.

The need to facilitate adoption of new technologies, particularly ICT, was ranked far lower than market forces in surveys of drivers of organisational change. This may reflect a lack of awareness of the synergies arising from joint implementation of organisational change and ICT. The adoption of ICT requires a flexible organisation at the same time that ICT increases the capacity to implement work flexibility. Organisational change can be a principal motivator for the introduction of new technology, just as obsolete technology can hinder the adoption of new organisational practices. Evidence, seen later in the paper, points to the need to couple new organisational practices with ICT offering opportunities for reducing costs and enhancing efficiencies along the entire business value chain. 


\section{ELEMENTS OF ORGANISATIONAL CHANGE}

Firm-level organisational change takes many forms, but can be classified into three broad streams: i) the restructuring of production processes; ii) management systems and employee involvement schemes; and iii) external re-organisation emphasising customer orientation, outsourcing, and firm networks and other collaborative arrangements (Table 3). Internal re-organisation typically affects the organisation of production approaches and work practices while external re-organisation is associated with the improvement of relations with customers and other firms. In practice, firms tend to apply an eclectic set of organisational practices, often spanning the three broad streams.

Table 3. Types of organisational change

\begin{tabular}{lll}
\hline Production approaches & Management practices & External relations \\
\hline & & \\
Total quality management & Decentralisation & Outsourcing \\
Lean production & Teamwork & Customer relations \\
Just-in-time & Knowledge management & Networking \\
Business re-engineering & Flexible work arrangements & \\
& Flexible compensation & \\
\hline
\end{tabular}

\section{Production approaches}

\section{Total quality management}

Total quality management (TQM) emphasises continuous quality improvement and is based on the assumption that the cost of quality (i.e. developing processes that produce high quality products and services) is less than the cost of poor workmanship (i.e. inspection, rework and lost customers) (Zell, 1997). TQM is based on: i) explicit knowledge about customer requirements and changes in processes; ii) suppliers chosen on the basis of product quality rather than solely on price; iii) teams to identify and solve quality problems; iv) statistical tools (control charts, Pareto analysis) for monitoring and continuous control; and v) process management tools to enhance team effectiveness. TQM allows for the fine-tuning of business processes but does not usually entail radical change nor fundamentally alter mass manufacturing systems of production.

TQM programmes are typically started and led by top management but require a multi-layered approach with both workers and management holding particular responsibilities. Production workers are given the means to control quality and to master quality control techniques, while management has overall responsibility for the different systems within which breakdown and defects can arise. TQM became popular in the 1980s, inspired by Japanese success with problem-solving "quality circles" that led to higher-quality products. However, attempts to create quality circles in certain companies in the United States were not as successful, due partly to problems in motivating workers (Zell, 1997). 
A 1993 survey of Fortune 1000 companies revealed that many companies implemented a few quality management practices -- mostly improvement or quality teams -- but rarely the whole systemic approach, making it difficult to evaluate the effectiveness of TQM in its entirety (Lawler et al., 1998).

\section{Lean production}

Lean production refers to the reduction of both inputs and time in production. After decades of domination by the Fordist mass production model, the Japanese automobile manufacturer Toyota recognised its drawbacks for the smaller Japanese automobile market and introduced a leaner approach. Variants have since been developed and adopted by industry worldwide. The mass production system combined a vertically integrated production structure, centralised decision-making and standardised products. It was built on special purpose equipment and elimination of skilled labour on the assembly line. Negative aspects include worker de-skilling, high rates of defective products and the need for large inventories of materials, components and finished goods to achieve economies of scale. Although the mass production model fuelled growth in the United States and other OECD countries for many years, it was gradually decentralised, diversified and replaced by leaner production approaches, more recently assisted by techniques such as simulation software (Box 1).

\section{Box 1: Simulation for lean production}

Simulation software allows firms to plan and test lean production approaches before actually implementing them. They can take designs through a dry run, set up production lines and create new products. Schneider Automation Inc. (United States) simulates the design and layout of printed circuit boards without making a prototype, allowing engineers to evaluate designs and layout, resulting in a $98 \%$ decline in manufacturing problems. DaimlerChrysler uses digital simulation to reduce the time it takes to build a car and to move from "product validation" to "process validation". The company can simulate inspection systems for checking component quality, including for engines and transmissions, both in the United States and in other countries. Simulation capabilities also allow for automatic updates when specifications change and offer different options and product combinations to meet customer demands.

Source: "Simulation Strategies", Industry Week, 17 July 2000.

Lean production involves the elimination of all sources of waste in company processes, including defective products, excessive inventory, inefficient work methods and handling of goods, and wasted time. The manufacturing process is adapted to lower volume production and a wider product and price range. Studies show that inventory reductions of up to $90 \%$ can be achieved through lean production techniques. In individual cases, increases in sales per employee and in productivity, of $40 \%$ and $72 \%$, respectively, have been recorded. However, some firms fail at or are disappointed with lean production implementation. Because it has a long learning curve, lean production needs to be led by top management who have received specialised training. In 2000, it was estimated that only $2 \%$ of all US firms had completed $80 \%$ of lean production implementation and only $3-4 \%$ of US firms were currently working on its implementation (Industry Week, 10 February 2000). 


\section{Just-in-time}

Just-in-time (JIT) is an element of lean production and refers to the organisation of production with minimum inventories. The "kanban" method -- as the original Toyota JIT version was called -- minimises inventories through continuous information flows transmitting details upstream on the precise quantities required at any stage of business from internal processes to external suppliers. JIT helps increase customer satisfaction through allowing greater customisation of products and reducing waiting time. It also reduces the cost of production by eliminating unnecessary stocks, realising gains in time and space, and promoting new approaches to warehousing and distribution.

Organisation of the entire supply chain is required for effective JIT implementation, which is dependent on the use of computers. In the 1980s, numerically controlled machine tools, robots and flexible transfer machines were introduced in Japan to fully implement just-in-time. IT-based manufacturing systems initially evolved separately from JIT, but they became increasingly interdependent. The automobile industry was one of the first to combine microelectronics-based and advanced IT technologies with just-in-time principles. Computer integrated manufacturing (CIM) systems now co-ordinate all aspects of production: the assembly line, production scheduling, ordering of components from external suppliers and JIT production within the plant. Based on minimal inventory, just-in-time is incompatible with extensive defects so it must be implemented in conjunction with quality control techniques. JIT has also been criticised for reducing worker participation in the different stages of production and distribution.

\section{Business re-engineering}

Business re-engineering, which came to prominence in the early 1990s, involves a fundamental rethinking or re-engineering of business processes in order to achieve significant improvements in performance, cost, quality, speed and customer service. It breaks away from traditional organisational structures conceived on functional lines, and views the firm as a system comprising a collection of processes which need to be smoothly aligned. This involves tracking materials from purchase point to delivery, including after-sales service and collection of used products for re-cycling (Monga, 2000). All processes, both technical and administrative, are included. It assumes that the efficiency of an enterprise depends on the rapid flow of information across the complete supply chain, from supplier to manufacturer to customer.

Emphasis in business re-engineering is put on critical activities, while non-core processes and those that do not add value, are considered to be candidates for elimination and outsourcing. The avoidance of unnecessary movement of material, inputs and finished goods is a basic principle, and gathering tasks into processes that involve minimum movement and communication is a main objective. The principle of continuous flow is integral to the system and is enhanced by IT applications. One tool is enterprise resource planning (ERP), which requires that every activity, material, worker and inventory be tracked, resulting in substantial data collection. When properly implemented, business re-engineering covers the entire range of business activities -- manufacturing, distribution, finance, project management, services, maintenance, and transportation -- with a view to creating seamless integration and consistency across the enterprise. It has also been associated with staff reductions and downsizing with some concomitant cost reductions and improvements in productivity (Lawler et al., 1998). 
DSTI/DOC(2002)14

\section{Management practices}

\section{Decentralisation}

The current wave of organisational change has involved a decentralisation of management responsibility and empowering of employees in order to achieve enhanced flexibility. Flatter hierarchies and devolved decision making can improve the flow of information within firms, the innovative and creative abilities of staff and responsiveness to clients. Staff performance can be enhanced if employees have the power to make decisions that influence organisational direction and performance. In addition, production approaches such as lean production and just-in-time as well as total quality management require more diffused decision-making structures and greater autonomy for production workers (Monga, 2000).

There are different forms and degrees of worker participation in decision making, including suggestion involvement, which does not necessarily entail the power to make decisions; job involvement, which offers employees more control over their routine jobs; and business involvement, which has greater employee participation in management decisions (Lawler et al., 1998). Another scheme classifies worker participation approaches into: i) "face-to-face" individual consultation; ii) "arm's length" individual consultation; iii) temporary group consultation; iv) permanent group consultation; $v$ ) individual delegation; and vi) group delegation. A survey of ten European Union countries in 1996 found that four out of five workplaces practised at least one form of worker participation, mostly consultation rather than delegation, but only $4 \%$ of workplaces used all six forms (European Foundation, 1997). Due to widely varying definitions of worker participation, it is difficult to measure its extent and compare workplaces across sectors and countries with regard to their degree of decentralisation.

\section{Teamwork}

Related to decentralisation is the rise of teamwork. Teamwork treats production as a system rather than as a set of individual jobs. It assumes that workers rather than managers or engineers know best how to organise work in the most productive manner possible, using a given technology. One aspect of teamwork is multi-skilling, which allows adaptability among personnel as technical change occurs, although it can sometimes be difficult to implement (Box 2). The importance of teamwork emerged in recognition of the need for functional flexibility within firms, i.e. the ability to switch workers between tasks. It gained in importance and scope in the 1970s and 1980s as a key feature of other organisational approaches such as total quality management (quality circles) and lean production.

Teamwork varies considerably depending on its purpose and the degree of autonomy or empowerment bestowed on team members. In supervised teams, a supervisor retains a central role in overseeing production which is carried out by groups of workers. Here, existing hierarchical structures remain almost the same, although workers may be frequently involved in decision making. In semi-autonomous or selfdirected teams, workers assume responsibility for most production decisions, but a supervisor or team leader has an extended span of control. Among those firms reporting the use of teams, most appear to use this level of team autonomy (e.g. the US firms Maxwell House and Harley Davidson). Few firms use purely autonomous teams without some degree of supervision (Appelbaum and Batts, 1994). 


\section{Box 2. Teamwork in the German pump industry}

In response to lower-cost competitors in Asia and Eastern Europe, German pumpmakers pursued greater functional flexibility by restructuring production processes and introducing flatter organisational structures. One aspect was the introduction of multifunctional work teams. However, the complexity and variety inherent in customised or small batch production found in much of the pump industry necessitated more specialised expertise. Implementation was hindered too by skilled workers who saw multi-skilling as threatening their status within the firm. A few plants adopted an alternative plant-within-a-plant concept while preserving individual worker skills and autonomy. Plants that initially had a less skilled workforce profited most from the introduction of multifunctional work teams. Overall, it is noted that the German apprenticeship system and work councils facilitated the transition to new, flatter, more flexible organisational forms.

Source: Finegold and Wagner (1998).

\section{Knowledge management}

Knowledge management is becoming a critical issue facing modern businesses as they seek means of extending, maintaining and exploiting their intangible assets, including management skills, employee competence, internal know-how and patents. A main emphasis is on the training and upskilling of employees. ICT applied to production and other functions is creating knowledge-intensive jobs demanding high skills. Just as important as preparing people to work with ICT is giving them the skills needed to work in firms where structures, environments and practices have been developed to accommodate ICT $(O E C D, 2001 c)$.

Firms are now developing their own customised training strategies, which are increasingly delivered on line (Box 3). They are establishing intra-firm educational organisations such as corporate universities using ICT technologies in various combinations of satellite-based learning, Web-based learning, virtual reality and virtual campuses, sometimes in conjunction with more traditional methods. This allows companies to rapidly disseminate new material to everyone in the value chain -- employees, customers and suppliers. In the Annual Survey of Corporate Universities undertaken in the United States, the share of training using advanced technology was estimated to be $18 \%$ in 1998 and $50 \%$ in 2000, and was most prevalent in manufacturing, transportation, communications, and utility firms. Companies and their contractors, service providers and strategic partners are also forming training networks to establish collaborative learning processes (Doyle, 2000).

\section{Flexible work arrangements}

More flexible workforces have meant a rise in the numbers of "hyphenated workers" where part-time, short-term, flexi-time, and self-employed workers constitute a growing share of employees. As firms downsize and streamline, there has been an increase in non-standard employment contracts where companies retain only core staff and use temporary and part-time staff to complement the workforce. A significant share of workers within large companies may be self-employed - paid by the company but registered with employment agencies. A large increase in part-time workers is also characteristic of flexible workforces as is the growing number of workers who work on temporary contracts. Another phenomenon is teleworking, where employees work from home but are linked to the workforce by information technology. In 1999, teleworking was practised by as much as $17 \%$ of the workforce in 
Finland, $15 \%$ in Sweden and the Netherlands, and an estimated $13 \%$ in the United States (Arnal et al., 2001).

These flexible work arrangements offer certain advantages to employers and employees. For firms, they provide maximum flexibility to adjust the size of the workforce to business cycles and demand trends. For workers, they can facilitate their mobility between different careers, jobs and markets. Part-time arrangements, teleworking and flexible working hours are favoured by women and men of all ages who wish to pursue alternative activities as a complement to work. However, employees on non-standard work contracts often do not enjoy the benefits associated with regular work contracts, including training, health insurance and pensions. The downside for employers of the increase in non-standard employment may come in the form of reduced loyalty or diminished incentives on the part of the workforce. There may be polarisation between protected and non-protected workers, and teamwork within the enterprise may be reduced.

\section{Box 3. ICT-based knowledge management}

FORDSTAR is a satellite-based learning system implemented by Ford Motor Company. It enables training, access to experts and product information, and networking opportunities for the 6000 dealerships in North America. Satellite-based training is considered cheaper, faster and more accessible than traditional training methods. Trainees can be reached in different locations simultaneously and benefit from real-time interaction. Lags between course development and course delivery are shortened. The system can log on participants in 1064 sites simultaneously, with a typical class size of 60 to 300 people. This system was found to make dealership employees more up-to-date, flexible and team-oriented.

DELL's concept of employee education has shifted away from workshops and classes towards Web-based tools. It now delivers 35-45\% of its curriculum through embedded learning systems, sometimes in conjunction with traditional teaching methods. One tool is the electronic performance support system which allows sales personnel to go on line and find product specifications, prices, competitor information, etc. The Dell learning approach also takes account of the way people learn, tracking how they locate specific information on line. It further offers the capability of customising learning experiences for individual needs and preferences, and the ability to measure performance.

ORACLE has created Oracle University, which is a virtual campus created for employees and partner organisations using Web-based learning. Oracle's product release cycle (only 8 to 18 months) and the target population of 32000 people necessitated a new approach. Oracle University provides a wide range of product and industry knowledge, technical skills, sales methods and company-specific processes. A major advantage is the low dependency on subject matter experts for course development and delivery.

MOTOROLA claims that using virtual reality to train employees on using complex chip-fabrication machines leads to better product quality and shorter cycle times. Virtual manufacturing labs were set up to train line workers by modelling the equipment. Employees can learn key concepts in a hands-on virtual environment. Experienced workers can perfect techniques. Motorola can "ship" virtual production lines to a manufacturing site for training purposes. The firm is also creating a library of virtual manufacturing equipment for new employees, comprising desktop programmes delivered via CD-ROM and upgraded through the company's intranet.

Source: Meister (1998). 


\section{Flexible compensation systems}

Firms are using flexible compensation programmes as a recruitment and retention tool in tight labour markets for skilled workers. They are experimenting with compensation to shape employee behaviour and to link worker performance more closely to the goals of the firm. Compensation generally comprises three components: base pay, variable pay (linked to performance) and indirect benefits (pensions, healthcare, family allowances). More types of variable pay are now being used, including gain-sharing, profit-sharing, lump sum bonuses, individual and group-based incentive pay and stock options. More flexibility is also being introduced to benefits provisions including pensions, healthcare, education and family policies.

Performance-related compensation is designed to strengthen employee incentives and increase trust and commitment. These practices can raise productivity through motivating employees and rewarding them for active participation in teamwork as well as for outstanding results and performance by the firm. Performance-based pay is being used by a substantial share of firms in OECD countries, particularly companies which are implementing a range of organisational changes (Table 4). Profit-sharing is widely used by large firms including multinationals operating in high-technology sectors. Stock options are often employed by small start-ups to attract and motivate employees; the value of stock options when redeemed may depend in large part on the performance of individuals and teams.

Table 4. Flexible compensation schemes (\% of firms)

\begin{tabular}{|l|cc|}
\hline & $\begin{array}{c}\text { Among firms that } \\
\text { implement } \\
\text { new practices }\end{array}$ & $\begin{array}{c}\text { Among firms that do not } \\
\text { implement } \\
\text { new practices }\end{array}$ \\
\hline $\begin{array}{l}\text { Australia (1995) } \\
\text { Any performance-based payment }\end{array}$ & 37 & 31 \\
Profit sharing & 7 & 4 \\
Stock options & 18 & 15 \\
European Union (EPOC survey 1994-96) & & 17 \\
Pay on basis of team output & 22 & 6 \\
Profit sharing & 25 & 43 \\
Ownership schemes & 10 & 66 \\
Finland (1996) & & 51 \\
Pay for the result of team or unit & 53 & 41 \\
France (REPONSE survey 1998) & & \\
Individualisation of wage increase & 76 & \\
Individual bonus & 54 & \\
United Kingdom (WERS survey 1998) & & \\
Any incentive payment scheme & 47 & \\
\hline
\end{tabular}

Note: Data are not comparable between surveys.

Source: Arnal et al. (2001).

A flexible programme can allow employees to structure the benefits package to best suit their preferences and adjust individual components as circumstances change. Increasingly, standard pension plans, health insurance and seniority-based compensation schemes are being replaced by more flexible approaches. For example, young employees may decide to accord less importance to pension aspects of the package. Single employees may give less importance to health insurance and family allowances. Some 
employees may accept to be compensated largely in terms of stock options. This allows firms to attract different types of employees, control the costs of benefits, introduce benefits at no cost, and enhance the firm's reputation as a leading-edge employer. However, such programmes also transfer more risk and responsibility to employees and may not be in their long-term interest. Flexible compensation schemes also tend to be less attractive in recessions and business downcycles.

\section{External relations}

\section{Outsourcing}

Outsourcing is now a main business strategy as firms contract certain activities to external suppliers and focus on their specialities and areas of strength. It can free up human and capital resources as well as allow for increased flexibility in how labour is employed. In contrast to earlier beliefs that outsourced activities were unimportant activities, it is now seen as a strategy for leveraging talent and resources. Outsourcing allows firms to benefit from state-of-the-art skills and technologies without having to invest in them or take associated risks. Studies show that there are potential benefits for firms in terms of improvements in cost, profitability, services, quality, access to technology and flexibility (Table 5).

Outsourcing involves the increasing use of subcontractors for the supply of components, subassemblies and services in sectors from computers to automobiles to textiles. A recent survey of global and European firms found that $63 \%$ of companies had outsourced one or more business process to external providers and $42 \%$ reported a company-wide shift to outsourcing major processes (PricewaterhouseCoopers, 1999). In Australia, manufacturing firms surveyed had outsourced at least one activity in 1996 and most were planning further outsourcing in the following three years (Benson and Ieronimo, 1996). Many firms outsource their information technology-related functions. Web-hosting refers to the outsourcing of Web site design and maintenance; application service providers provide various software applications and tasks on a subscription basis; and Internet services providers (ISPs) provide feebased access to Internet applications and resources. The Outsourcing Institute estimates the European IT outsourcing market to be currently around USD 27 billion.

Table 5. Reasons for outsourcing

Reasons for outsourcing $\quad \%$ of respondents

$\begin{array}{lr}\text { Achieve cost savings } & 79 \\ \text { Focus on core competencies } & 75 \\ \text { Improve level of service } & 70 \\ \text { Maintain competitive edge } & 67 \\ \text { Increase shareholder value } & 62 \\ \text { Gain expertise from outside organisation } & 61 \\ \text { Meet changing customer demands } & 60 \\ \text { Access advance technologies } & 59 \\ \text { Achieve revenue enhancements } & 58 \\ \text { Make continuous process improvements } & 58 \\ \text { Achieve world-class standards } & 53 \\ \text { Ensure greater internal flexibility } & 52\end{array}$

Note: Responses to survey of global and European firms. Source: PricewaterhouseCoopers (1999). 
There are certain risks associated with outsourcing. A firm may forego a measure of control over activities, and core products or technologies could be compromised. A firm may become dependent on a large range of suppliers, and product and service providers may not live up to expectations. Outsourcing decisions once taken are difficult to reverse, and the attendant human capital and skills associated with the outsourced activity are difficult to restore once lost. Outsourcing is also associated with "downsizing" which has negative labour-shedding connotations. While outsourcing can lead to smaller firms and reduced workforces, employment effects can also be positive in the long term due to improved firm performance and the creation of smaller service and product suppliers. However, little is known about the long-term consequences for enterprise performance of outsourcing, which is still a relatively recent phenomenon on a larger scale.

\section{Customer relations}

Intensified competition can lead to declining customer and brand loyalty and is a major reason for heightened attention to customer relations. Research indicates that the cost of acquiring new customers is five times greater than the cost of keeping old ones (The Technical Assistance Resource Project for the US Office of Consumer Affairs cited by Perspectives, CapGemini). To retain customers, firms have to focus more on the unique value that their products and services offer to their customers. They are also implementing comprehensive approaches that go beyond traditional marketing departments. Customer relationship management (CRM) involves acquiring a customer focus and defining a strategy around customer needs rather than product features. Comprehensive knowledge of customers equips firms to innovate and anticipate market trends.

Firms use a variety and combination of tools and channels, many based on ICT, in their customer relations (Figure 1). Sales forces in the field are supplemented by interactive Web sites and call centres. Advanced database technology, World-Wide Web integration, sales force automation and multimediabased front office applications are the foundation for communicating with clients. E-sales, e-banking, e-retailing and e-services are interlinked. Data warehousing, data mining, data cleansing, and data models have replaced traditional customer surveys and enabled firms to extract precise knowledge about customer behaviour to be used at the different customer contact points. As a result, the market for professional CRM services is large and growing. The European market is expected to grow from USD 1 billion to USD 7 billion in 2003. Japan's CRM service market is projected to more than double to USD 2.17 billion by 2004 (CapGemini, 2000).

Almost four fifths of firms use "Call Centre" applications as a CRM tool (Figure 1). Firms are removing and consolidating particular service activities -- such as customer care, technical support and direct marketing -- from different units of their businesses. Such amalgamated activities or Shared Services Centres may be owned and operated by the parent company, but are increasingly being outsourced to third-party providers. These Call Centres provide telemarketing, technical sales support, logistics and distribution of products, financial services such as customer loans, and follow-up services. Recent growth reflects heightened emphasis on customer relations management as well as information technology developments, including deregulation in telecommunications markets.

\section{Networking}

Collaboration or networking among firms has accompanied the trend to downsizing and outsourcing. Inter-firm networks can provide access to resources such as information or technology; economies of scale and scope in production or services; acquisition of skills and knowledge through joint training or research; and risk-sharing. Networks span a range of activities, including transfer of learning, sharing of information, 
joint purchasing, co-production, joint marketing, etc. The ability to participate successfully in a range of networks and consortia is considered a key to firm competitiveness and productivity performance in the "new economy" context (Carayannis and Sagi, 2001). Enterprises which are grouped in functional or regional clusters or networks tend to outperform those that are not $(O E C D, 2001 d)$.

Networks take many forms. Informal networks allow firms to co-operate without a "brokering" intervention. Membership-based networks include traditional industry associations where a firm's performance is not linked to the action of other firms. Developmental networks involve collective learning and mentorship within a group, such as human resource and training networks. In joint action networks, firms share a common resource (e.g. export activities, transport or production equipment). Project networks (or strategic alliances) are instituted by firms with complementary resources and skills and relate to activities with a specific goal, such as joint research. Joint ventures are more formal alliances to manage particular product development or marketing activities (Doyle, 2000). Increasingly, firms are collaborating in a range of activities through virtual or electronic networks.

Figure 1. CRM tools in US and European enterprises

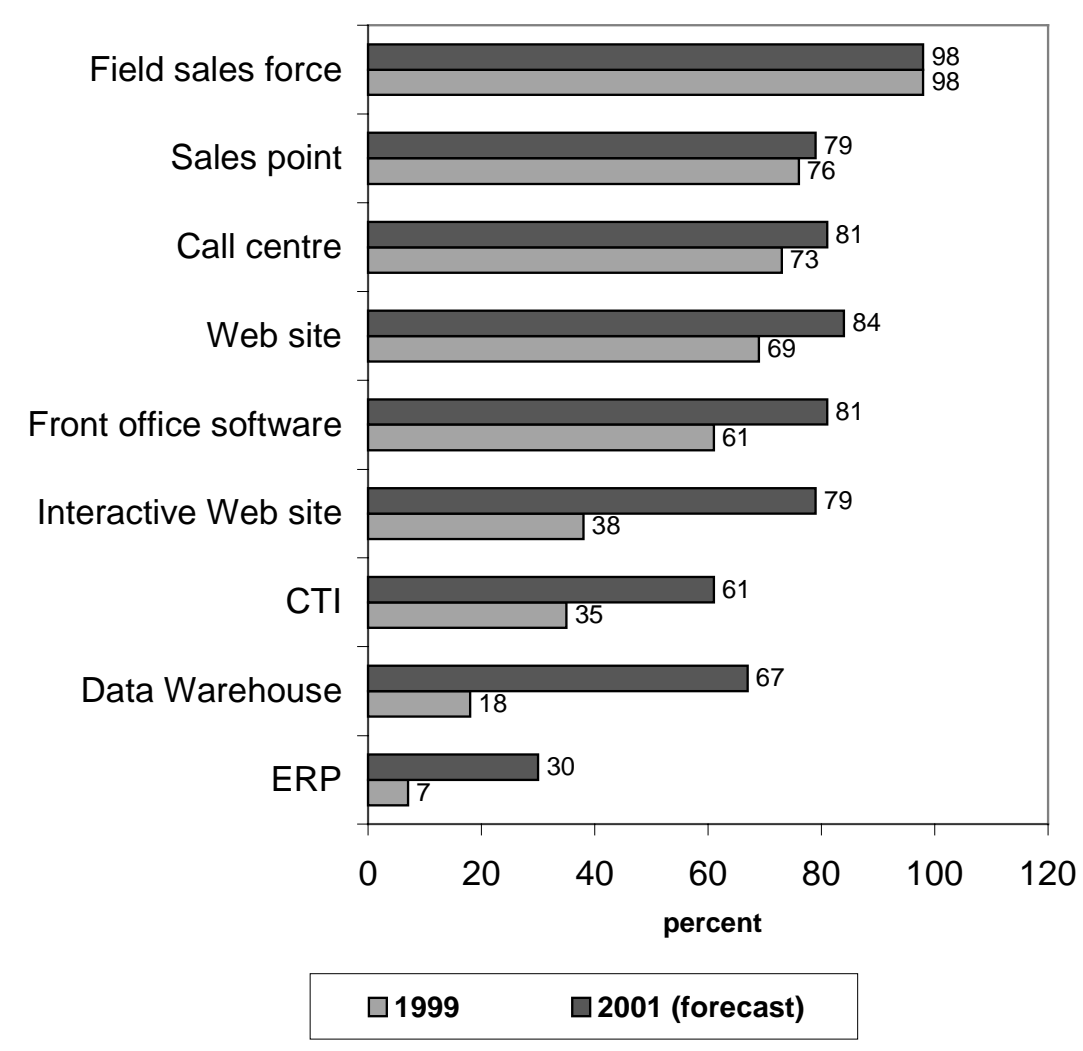

Source: IDC and CapGemini (2000). 


\section{THE EFFECTS OF ORGANISATIONAL CHANGE ON FIRM PERFORMANCE}

Firms can improve their performance in terms of productivity, efficiency and innovation and their international competitiveness through reorganisation of their structures and processes. Several studies attest to the positive performance effects, in particular productivity gains, when single organisational practices -- e.g. lean production, quality controls, increased training, etc. -- are implemented. However, in many cases, the performance improvements may occur only after a certain time lag or with initial adjustment costs including labour shedding.

More successful is the introduction of complementary organisational changes. The implementation of bundles of high-performance practices, as opposed to single practices, is very beneficial for firms. Synergies exist between incentive pay schemes, the use of work teams, and enhanced training for production workers (Ichniowski, 1990). The bundling of production and human resource management practices is particularly effective (Black and Lynch, 2000). Firm performance has been shown to improve with investments in flexible employee management and compensation programmes together with process and total quality management programmes (Mavrinac and Siesfeld, 1998).

\section{Production approaches}

The implementation of new production approaches -- such as total quality management, lean production, just-in-time and business re-engineering -- can result in substantial improvements in firm efficiency and productivity. US firms recognised for their "above average implementation" of a total quality management programme achieved excess share returns amounting to $15 \%$ over the five-year period following the programme launch (Jarrell and Easton, 1996). Business re-engineering, which is based on leaner production and continuous flows, reduced lead times (56\%), inventories (44\%) and reject and scrappage costs (46\%) significantly in US firms surveyed (Table 6). A case study of business reengineering applied to air cargo handling processes showed dramatic improvements in operational efficiencies and a reduction in the number of steps and time needed to complete different phases of the business operation (Table 7).

Table 6. Performance effects of business re-engineering (US firms)

\begin{tabular}{llll}
\hline & & & $-54.1 \%$ \\
Set-up time & $-66.4 \%$ & Distance travelled per part & $-29.4 \%$ \\
Lead time & $-55.7 \%$ & Floor space & $-57.0 \%$ \\
Cycle time & $-17.9 \%$ & Parts required per unit & $-95.0 \%$ \\
Down time & $-52.1 \%$ & Cost of quality rejects & $-71.7 \%$ \\
Operators required & $-32.0 \%$ & Rework & $-45.9 \%$ \\
Work-in-process & $-59.3 \%$ & Scrap & $-34.0 \%$ \\
Final goods inventory & $-43.5 \%$ & Equipment required & \\
\hline
\end{tabular}

Source: Monga (2000). 
DSTI/DOC(2002)14

Table 7. Effects of Business Process Re-engineering (BPR) in air cargo handling

\begin{tabular}{lccrc}
\hline \multicolumn{1}{c}{ Step } & Before BPR & Before BPR & After BPR & After BPR \\
& Steps & Minutes & Steps & Minutes \\
& & & & 620 \\
Operation & 59 & 1652 & 4 & 120 \\
Transportation & 22 & 675 & 0 & 0 \\
Delay & 22 & 513 & 4 & 90 \\
Inspection & 12 & 425 & 2 & 435 \\
Storage & 5 & 1610 & $\mathbf{1 8}$ & $\mathbf{1 2 6 5}$ \\
Total & $\mathbf{1 2 0}$ & $\mathbf{4 8 7 5}$ & & \\
\hline
\end{tabular}

Source: Khan (2000).

However, the introduction of these production approaches is not always successful. Some firms find such approaches too complicated to implement and associated with new inefficiencies. They may also fail because they are implemented before the necessary redesign of related processes has occurred (Lockamy and Smith, 1997). While contributing to productivity increases, many newer production approaches can have far-reaching structural effects on plants and on employees (Box 4). They may be too focused on streamlining and downsizing and espouse values that run counter to organisational and individual development and learning. Studies have found that adoption of business re-engineering or total quality management can have an insignificant or even negative impact on productivity unless the proportion of workers involved in regular decision-making within the plant is also high (Clegg et al.,1997).

\section{Box 4. Lean production and productivity}

Trane, a subsidiary of the US manufacturing group American Standard, implemented a series of efficiency improvements using techniques such as just-in-time production, demand flow technology and Six Sigma, which resulted in a substantial increase in productivity. The plant halved the time it takes from order to delivery of its furnaces and doubled the number of units produced by each employee. As a result, the plant reduced inventory levels substantially and became the largest manufacturing employer in the area (partly because some competitors failed). In other factories belonging to the same firm, implementation of these practices and impacts on efficiency resulted in one factory working at only half capacity and eventually led to its closure. The company then transferred the work to another factory as productivity improvements there had freed up capacity. In general, the implementation of lean production was accompanied by substantial impacts on facilities and employees, which may necessitate complementary actions to facilitate structural adjustment.

Source: Financial Times, 9 March 2001, "Lean Times for a Lean System”.

The employment implications of new production approaches are mixed. Although associated with labour shedding in the short term, organisational change and restructuring can lead to employment growth in the longer term as more efficient firms prosper and expand. In Canadian firms introducing new production approaches, employment grew in $29 \%$ of firms, remained stable in a further $27 \%$, but declined 
in almost $44 \%$ of firms. Where employment increased, it grew faster $(81 \%)$ than the employment decline (31\%) in firms laying off workers (Magun, 1998). For Nordic countries, a reduction in the number of employees and managers occurred in around one-third of workplaces implementing organisational change. However, employment grew fastest among front-runners who also improved their productivity (Nutek, 1999).

\section{Management practices}

The adoption of "flexible" management practices -- including decentralisation, teamworking, job rotation, training and innovative compensation schemes -- appears critical to realising productivity benefits from new production approaches. Organisational practices that encourage different forms of worker involvement in the improvement of production processes are strongly associated with increased firm productivity (Ichniowski, 1990). Other studies find that enhancing workplace participation can have longlasting effects on productivity when it involves decisions that extend to the shop floor and substantive participation in decision making by front-line workers. In contrast, consultative arrangements such as quality circles -- which involve information sharing rather than decision making -- have more short-lived benefits (Kling, 1995). Workplaces with no participative culture are significantly outperformed by those with more innovative management practices, particularly when small workplaces are included in the sample (Nutek, 1999).

In particular, project teams and matrix organisations have been found superior to traditional management structures for meeting project deadlines, cost and technical performance objectives (Lee et al., 2000). Changes in a firm's human resource strategy -- including more employee participation, incentive pay and training -- are associated with significant gains in cash flow, profits and firm market value (Huselid and Becker, 1996). Profit sharing in US firms was found to increase productivity in a majority (57\%) of firms and reduce defect and downtime rates by $23 \%$ in the first year (Kling, 1995).

Staff training is positively correlated with productivity performance, although with lagged results. In the short term, training investments can lead to a drop in productivity due to the initial adjustment costs associated with the introduction of new workforce skills. Moreover, studies find that the greater the proportion of time spent in formal off the job training, the higher the productivity rise because: $i$ ) training workers outside working hours lowers the output loss associated with on-the-job training; and ii) employers that train their workers off the job may be investing in more advanced and more timeintensive skills development. For non-manufacturing firms, the content of training has an important impact on productivity, particularly computer skills development (Black and Lynch, 1996). Training is also associated with improved quality in output and reductions in scrapping (Kling, 1995).

Employee involvement and effective labour-management relationships are key to fostering organisational change and raising productivity $(O E C D, 2001 a)$. Many studies find that union presence has positive effects on productivity by lowering the costs of introducing new workplace practices and encouraging worker participation. New work practices are also more prevalent among unionised firms and those with work councils (Arnal et al., 2001). Studies of unionised firms in the United States found that with unions in place, several management approaches -- e.g. increasing the share of non-managers using computers, having workers meet regularly to discuss workplace issues, profit-sharing for non-managers, self-managed worker teams plus total quality management -- yielded productivity increases of $20 \%$ above the base case. Firms that adopted joint decision-making and incentive-based compensation had higher productivity than similar non-unionised plants or unionised plants with traditional labour-management relations. However, negative productivity outcomes can occur if unions restrain management choices or pursue restrictive practices (Black and Lynch, 1997). 


\section{External relations}

Productivity increases and performance benefits are being seen in firms that alter their external relations to focus more on clients and networking. In a survey of Danish firms, those adopting new external practices realised higher productivity increases than those which did not (Table 8). These included outsourcing of production and services, strategic alliances, joint ventures and mergers and acquisitions. The direction of change appeared less important than the attention paid to initiatives that improved the division of labour with external suppliers. Collaborating and entering into networks and alliances with other firms was very advantageous (Danish Ministry of Business and Industry, 1996). Enteprises operating in clusters with related firms in supply chains generally outperform those which do not (OECD, 2001d).

Other studies find that efforts to streamline business processes, improve product and service delivery and enhance supplier-customer relations increase innovation within firms and the exploitation of new technologies. Alliances with customers and suppliers enhanced innovation and marketing in Australian manufacturing firms (Sohal et al., 1999). Adopting technology-based customer relations management techniques is positively correlated with productivity increases, particularly in service sectors.

Table 8. Annual growth in productivity by external changes* in Danish firms

\begin{tabular}{lcc}
\hline Category of external relations & Firms with changes & Firms without changes \\
\hline & & $0.7 \%$ \\
Outsourcing of production & $2.8 \%$ & $1.5 \%$ \\
Outsourcing of services & $0.9 \%$ & $1.1 \%$ \\
Strategic alliances & $2.4 \%$ & $1.3 \%$ \\
Joint ventures & $3.7 \%$ & $1.6 \%$ \\
Mergers & $1.9 \%$ & $1.1 \%$ \\
Acquisitions & $2.7 \%$ & \\
& & \\
\hline * Changes in external relations occurring during 1984-94. & \\
Source: Danish Ministry of Business and Industry (1996). &
\end{tabular}




\section{STRUCTURAL FACTORS AND ORGANISATIONAL CHANGE}

Structural factors can play a significant role in the nature and extent of organisational change, its impacts on the performance of firms, and the interactions between organisational change and ICT investments. Work organisation can vary considerably by country, by industrial sector and by firm size.

\section{Countries}

Many approaches to the organisation of work and production -- most of which were developed to gain a competitive advantage over mass-production models -- are associated with their country of origin (Table 9). In the United States, firms now apply an eclectic set of organisational practices, many of them originating in other countries, including lean production, just-in-time and quality circles. They have moved away from earlier mass-production approaches which had little teamwork and poor management-union relations. American lean production is centralised, emphasises training, and focuses on quality management, process management and re-engineering. US firms tend to be the leaders in certain human resource applications, including incentive compensation structures. American teamwork, most often associated with unionised workplaces, is decentralised, involving self-directed work and quality engineering. A survey of 3000 establishments in 1993-96 revealed that, in addition to employee participation and training, two-fifths of companies had profit-sharing schemes, $25 \%$ had recently undertaken re-engineering and almost one in five had self-managed teams (Figure 2).

Figure 2. Workplace practices in the US establishments

Percentage of companies using various practices (Survey based)

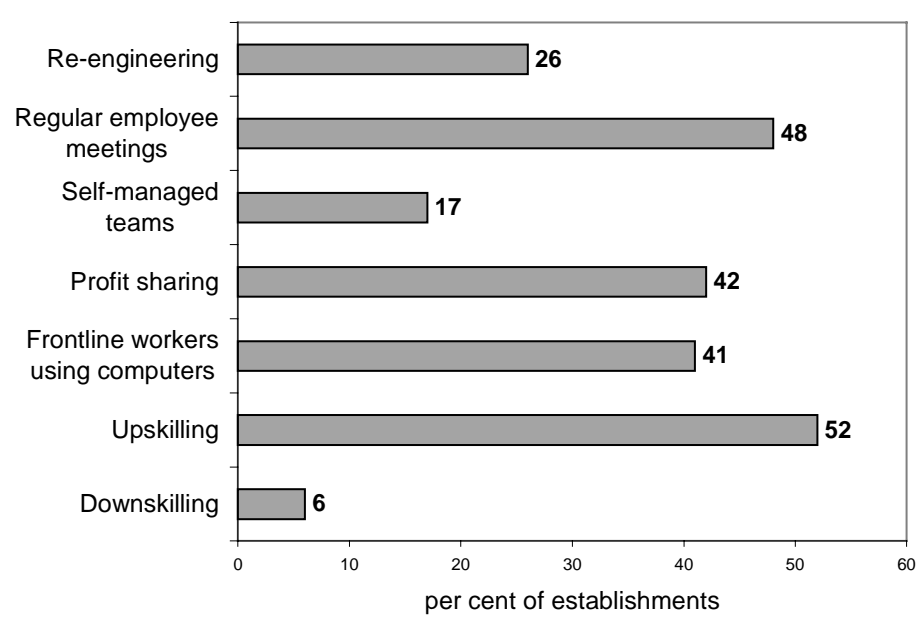

Source: Black and Lynch (2000). 
Table 9. Country models of organisational change

\begin{tabular}{|c|c|c|c|c|c|}
\hline & $\begin{array}{l}\text { MASS } \\
\text { PRODUCTION } \\
\text { MODEL (US) }\end{array}$ & $\begin{array}{l}\text { SOCIOTECHNICAL } \\
\text { SYSTEMS } \\
\text { (SWEDEN) }\end{array}$ & $\begin{array}{l}\text { LEAN PRODUCTION } \\
\text { (JAPAN) }\end{array}$ & $\begin{array}{l}\text { FLEXIBLE } \\
\text { SPECIALISATION } \\
\text { (ITALY) }\end{array}$ & $\begin{array}{l}\text { QUALITY } \\
\text { PRODUCTION } \\
\text { (GERMANY) }\end{array}$ \\
\hline Structure & $\begin{array}{l}\text { Centralised } \\
\text { Hierarchical }\end{array}$ & Centralised Flatter & Centralised Flat & $\begin{array}{l}\text { Decentralised } \\
\text { Collaborative }\end{array}$ & $\begin{array}{l}\text { Centralised } \\
\text { Hierarchical }\end{array}$ \\
\hline Employee involvement & No & $\begin{array}{l}\text { Informal, by work } \\
\text { teams }\end{array}$ & Yes, quality circles & No & No \\
\hline Work reform driven by & Management & Workers & Management & Small firms & Union \\
\hline Shop-floor teams & No & Self-directed & Supervised & Small work groups & No \\
\hline Jobs rotate/enlarge & Some & Yes & Yes & Yes & No \\
\hline Vertical tasks & No & Yes & No & & No \\
\hline Integration of horizontal tasks & Some & Yes & Yes, substantial & High & Some \\
\hline Depth of knowledge & Limited & $\begin{array}{l}\text { Team characteristic, } \\
\text { not individual }\end{array}$ & $\begin{array}{l}\text { Trade-off depth for } \\
\text { greater breadth }\end{array}$ & $\begin{array}{l}\text { Craft know-how } \\
\text { widespread but many } \\
\text { unskilled workers }\end{array}$ & $\begin{array}{l}\text { In-depth operational } \\
\text { and analytical craft } \\
\text { know-how }\end{array}$ \\
\hline Flexibility in deploying workers & Some & High & High & Very high & Negotiated adjustment \\
\hline Skills training & Yes & $\begin{array}{l}\text { Public } \\
\text { education/training }\end{array}$ & Yes, on the job & $\begin{array}{l}\text { Yes, formal and on the } \\
\text { job }\end{array}$ & Yes, apprenticeship \\
\hline Cross training & Some & $\begin{array}{l}\text { High, though not } \\
\text { every worker can do } \\
\text { every job }\end{array}$ & $\begin{array}{l}\text { High, every worker can } \\
\text { do every job in work } \\
\text { group }\end{array}$ & $\begin{array}{l}\text { Relatively high, through } \\
\text { other firms }\end{array}$ & $\begin{array}{l}\text { Yes, but only within } \\
\text { particular craft }\end{array}$ \\
\hline $\begin{array}{l}\text { Team-building } \\
\text { Individual incentives: }\end{array}$ & No & Yes & Yes & No & No \\
\hline Merit raises & Yes & No & No & No & No \\
\hline Gainsharing & No & Yes & No & $\begin{array}{l}\text { Local wages tied to } \\
\text { territorial productivity }\end{array}$ & No \\
\hline Stock options & Some & No & No & No & No \\
\hline Unions & $\begin{array}{l}\text { Low rate of } \\
\text { unionisation }\end{array}$ & $\begin{array}{l}\text { Strong, national } \\
\text { unions represent vast } \\
\text { majority }\end{array}$ & Enterprise unions & High rate of unionisation & Strong, industry unions \\
\hline Power sharing & $\begin{array}{l}\text { Communication and } \\
\text { consultation through } \\
\text { employee suggestion } \\
\text { surveys }\end{array}$ & $\begin{array}{l}\text { Co-determination } \\
\text { Joint labour } \\
\text { management } \\
\text { committees }\end{array}$ & $\begin{array}{l}\text { Joint consultation } \\
\text { committees } \\
\text { Ringi system for } \\
\text { communication/consens } \\
\text { us building }\end{array}$ & $\begin{array}{l}\text { Work councils Unions } \\
\text { typically negotiate right } \\
\text { of information on firm's } \\
\text { activities and } \\
\text { investments }\end{array}$ & $\begin{array}{l}\text { Work councils } \\
\text { Co-determination }\end{array}$ \\
\hline
\end{tabular}

Source: Appelbaum and Batts (1994). 
Lean production originated in Japan, where it differs from the North American model in a number of respects: Japanese workers participate more in continuous improvements efforts; quality circles involve permanent employees in contrast to temporary functional teams; employment security is important and employee suggestions have a high implementation rate. Outsourcing is a key feature of Japanese just-intime approaches and subcontracting is extensive (Castley, 1995). The tradition of lifetime employment with one company is weakening in Japan, with growing numbers of temporary workers and more performance-based pay (Kruger and Fuyuno, 2001). Team concepts, first applied in the automobile industry, have spread to other industries, resulting in a higher horizontal flexibility in production than can be found, for example, in European firms (Köhler and Woodward, 1997).

In Australia, one survey found that the majority of manufacturing firms use work teams as well as quality certification programmes, quality teams, and continuous improvement programmes. Total quality management and workforce empowerment practices are widespread. Like their Canadian counterparts, Australian workers receive approximately six days of training annually. The vast majority of firms reimburse tuition fees while two in three firms offer apprenticeships and opportunities in co-operative third level educational programmes. For product and process development, Australian firms prefer alliances with customers and suppliers (Sohal et al., 1999).

A number of major work organisation approaches originated in Europe, including the Swedish sociotechnical systems, the Italian flexible specialisation system and the German diversified quality production system (Appelbaum and Batts, 1994). Socio-technical systems use production teams to combine design with improvements in the quality of goods. Italian flexible specialisation combined with networking gives small or decentralised firms the capability to innovate rapidly and to respond promptly to customer demand for product variation. The German diversified quality production system enables producers to supply high-performance, customised products that do not compete on the basis of price, to the high end of the market. The German training system, works councils and unions play a crucial role in strategic decision making in the firm.

Among European enterprises, Nordic firms tend to be "front-runners" in adopting practices such as devolved responsibility, skill development programmes, teamworking, job rotation and incentive-based compensation (Nutek, 1999). France has high differentiation of functions and tasks, and French production workers tend to have little participation in planning and servicing functions (Köhler and Woodward, 1997). In a pan-European survey, the Netherlands and Sweden had the highest incidence of workplace participation, and Portugal and Spain the lowest. Fewer initiatives for teamworking were recorded in Germany and the Netherlands where work councils may already be involved in such co-operation (European Foundation, 1998).

Corporate and national cultures and regulatory frameworks influence national work practices and patterns of organisational change. For example, cross-country comparisons find that whereas Canadian firms emphasise new production approaches and flatter structures in their organisational changes, Australian firms tend to focus on forming alliances with customers to assist product development (Sohal et al., 1999). A comparative study of Korean and US enterprises attributed differences in organisational approaches largely to culture, with Korean firms emphasising hierarchy, seniority and group achievements, and American firms highlighting individual achievement and performance-based incentives (Lee et al., 2000). Studies of Japanese and US firms reveal that Japanese firms tend to be less inclusive in decision making and participation by a wide range of employees and managers (Tsuji, 2001). 


\section{Sectors}

In recent years, organisational change has been practised more by firms in certain service sectors than in manufacturing, in contrast to earlier implementation patterns (Appelbaum and Batts, 1994; Magun, 1998). However, there are indications that once undertaken, organisational change tends to be more radical and far-reaching in manufacturing firms. In both manufacturing and services, firms that are exposed to international competition, and those in industries confronted with increasingly short product life cycles (e.g. electronics) have higher rate of implementation. Studies of the distribution of organisational efforts by sector show quite a high rate of implementation of flexible practices by the financial sector (Tables 10 and 11).

Table 10. Organisational change by sector

Nordic countries, \% of firms

\begin{tabular}{|c|c|c|c|c|c|}
\hline Country & Sector & Size: $>50$ & Country & Sector & Size: $>50$ \\
\hline \multirow[t]{6}{*}{ Sweden } & Manufacturing & 13.9 & Denmark & Manufacturing & 13.6 \\
\hline & Construction & 5.5 & & Construction & 4.4 \\
\hline & Trade & 15.1 & & Trade & 14.8 \\
\hline & Communications & 9.1 & & Communications & 6.7 \\
\hline & Finance & 17.4 & & Finance & 9.1 \\
\hline & Other & na & & Other & na \\
\hline \multirow[t]{6}{*}{ Finland } & Manufacturing & 14.5 & Norway & Manufacturing & 5.6 \\
\hline & Construction & 3.6 & & Construction & 6.0 \\
\hline & Trade & 12.6 & & Trade & 3.6 \\
\hline & Communications & 2.9 & & Communications & 0.0 \\
\hline & Finance & 24.7 & & Finance & 6.5 \\
\hline & Other & na & & Other & 7.0 \\
\hline
\end{tabular}

Table 11. Organisational change by sector

Canada, \% of firms

Industrial sector

Agriculture, fishery, \& forestry

Metal, oil extraction \& non-metallic minerals

Construction

Manufacturing

Communications, transportation \& public utilities

Trade - wholesale and retail

Finance, insurance \& real estate (FIRE)

Services - personal, health communications

Total
Firms that underwent restructuring

All firms

$\begin{array}{rr}0.5 & 0.5 \\ 19.5 & 29.1 \\ 0.5 & 1.1 \\ 25.2 & 17.5 \\ 10.0 & 4.2 \\ 7.0 & 10.9 \\ 29.9 & 28.8 \\ 7.2 & 8.0 \\ 100 & 100\end{array}$

Source: Magun (1998). 
Different sectors are associated with particular organisational change approaches. Manufacturing firms tend to focus on the introduction of new production approaches made possible by advances in computers, numerically controlled machines and robots and affecting a host of industries including machinery, fabricated metal, electronic and electrical equipment. In automobiles, for example, adoption of lean production was a prerequisite for capturing the full benefits of machine tools and robotics (Womack and Roos, 1990). Some light manufacturing industries, such as food, textiles and paper products, appear to have been less affected by restructuring. Supply chains that are driven by retailers (found in labourintensive industries such as apparel and footwear) are often associated with lower rates of employee involvement and organisational change. Sectors such as textiles and apparel have focused on improving distribution, just-in-time systems and quick response methods.

In services, organisational change is largely directed to increasing employee participation and teams so as to improve quality and customer relations. Total quality management systems are useful for developing indicators of previously unmeasurable performance such as service quality. Services also tend to offer more employee training than manufacturing firms. In the European Union, financial services, utilities, car repair services, real estate and business services lead all other industries in the provision of training, while textiles and clothing firms have the lowest rate (Table 12). In retail distribution, organisational change is oriented to improving customer service through leaner, computer-operated systems in conjunction with employee training and teamwork. On average, the share of retail and wholesale businesses offering training was 64\% and 57\% respectively in 1993 (CEDEFOP, 1997). Sectoral differences also exist with respect to the delivery of training using ICT, which is more common in service sectors (Meister, 1998).

Table 12. Firm-level training by sector

European Union

\begin{tabular}{llll}
\hline Sector & $(\%)$ & & $(\%)$ \\
& & & 58 \\
Banking \& insurance & 87 & Hotels \& restaurants & 57 \\
Electricity gas \& water & 81 & Non-metallic products & 57 \\
Other financial services & 79 & Wholesale trade (excl. vehicles) & 56 \\
Sale \& repair of vehicles & 78 & Transport equipment & 51 \\
Real estate, renting \& services for enterprises & 72 & Construction & 49 \\
Post \& communications & 66 & Food, beverages \& tobacco & 46 \\
Retail trade \& repairs (excl. vehicles) & 64 & Transport \& storage & 43 \\
Manufacture of machinery & 62 & Mining \& quarrying & 41 \\
Manufacture of metals \& metal products & 59 & Other manufacturing & 26 \\
Paper, publishing \& printing & 59 & Textiles clothing \& leather & \\
Total & 57 & &
\end{tabular}

Notes: Share of firms in sector offering training, 12 EU countries, 1993.

Source: CEDEFOP (1997).

\section{Firm size}

In most sectors, smaller firms are less likely to undertake organisational changes than larger firms largely because of information and resource gaps. In Canada, firms employing more than 200 employees are twice as likely to introduce new production and work processes than are smaller firms (Statistics Canada, 1998). In a 1996 survey of Canadian small businesses (less than 20 employees), only one-third had introduced any type of organisational changes in the previous three years (Gellatly, 1999). In the 
Nordic countries, the share of small firms (employing fewer than 50 employees) that could be classified as having a flexible organisation was about half that of larger firms (Nutek, 1999).

There are a number of variables that influence the decisions of small firms to invest in organisational change. Small establishments which are branch plants of larger enterprises tend to make these investments at two to three times the rate of independent SMEs (Nutek, 1996). Profitability and competitive pressures also play a important role. Smaller firms experiencing increases in rates of return and growth were less likely than larger firms to undertake restructuring (due to reduced market pressures) than larger firms (Magun, 1998). In France, shareholders played a large role in decisions by large firms to reorganise, while the regulatory environment and the influence of suppliers and sub-contractors were important drivers of change in smaller enterprises (Table 13).

Table 13. Factors driving organisational change in SMEs

France, 1994-97, \%

\begin{tabular}{lccc}
\hline & All firms & SMEs & Large firms \\
\hline Competition & 74.9 & 74.7 & 82.2 \\
Market uncertainty & 65.8 & 66 & 58.9 \\
Constraints imposed by: & 75.5 & 75.8 & 74.2 \\
$\quad$ Customers & 25.0 & 25.0 & 14.2 \\
Suppliers, subcontractors & 41.5 & 33.0 \\
Regulations & 17.2 & 16.9 & 36.0 \\
Mergers, acquisitions, cessations & 17.4 & 16.6 & 43.7 \\
Shareholders or group & 95.3 & 95.3 & 97.3 \\
At least one constraint & 3.2 & 3.2 & 3.4 \\
Average number of constraints & & & \\
& & &
\end{tabular}

Large and small firms can differ with respect to the types of organisational changes that they are likely to implement, a study of Canadian firms revealed (Statistics Canada, 1998). Large firms are more likely to provide training and skills development than SMEs, to increase worker participation in decision-making and to be unionised. Employee training was also found to increase with firm size, with almost $50 \%$ of staff receiving training in larger firms compared to about $26 \%$ in firms with less than 19 employees. In France, large firms were found to be more likely to institute quality improvements and to acquire certification and accreditation, for example under ISO guidelines (International Organisation for Standardisation) (SESSI, 2001). When the intensities of different organisational strategies are measured and compared across size bands, larger firms (in Canada) emerged with higher investments in human resource, cost reduction and quality improvement strategies (Figure 3). Concerning the benefits to be derived from organisational change, studies show that changes in management structure and work organisation can procure higher marginal benefits for SMEs than for larger firms (Bryson, 1999). 
Figure 3. Organisational strategies and firm size

Canada

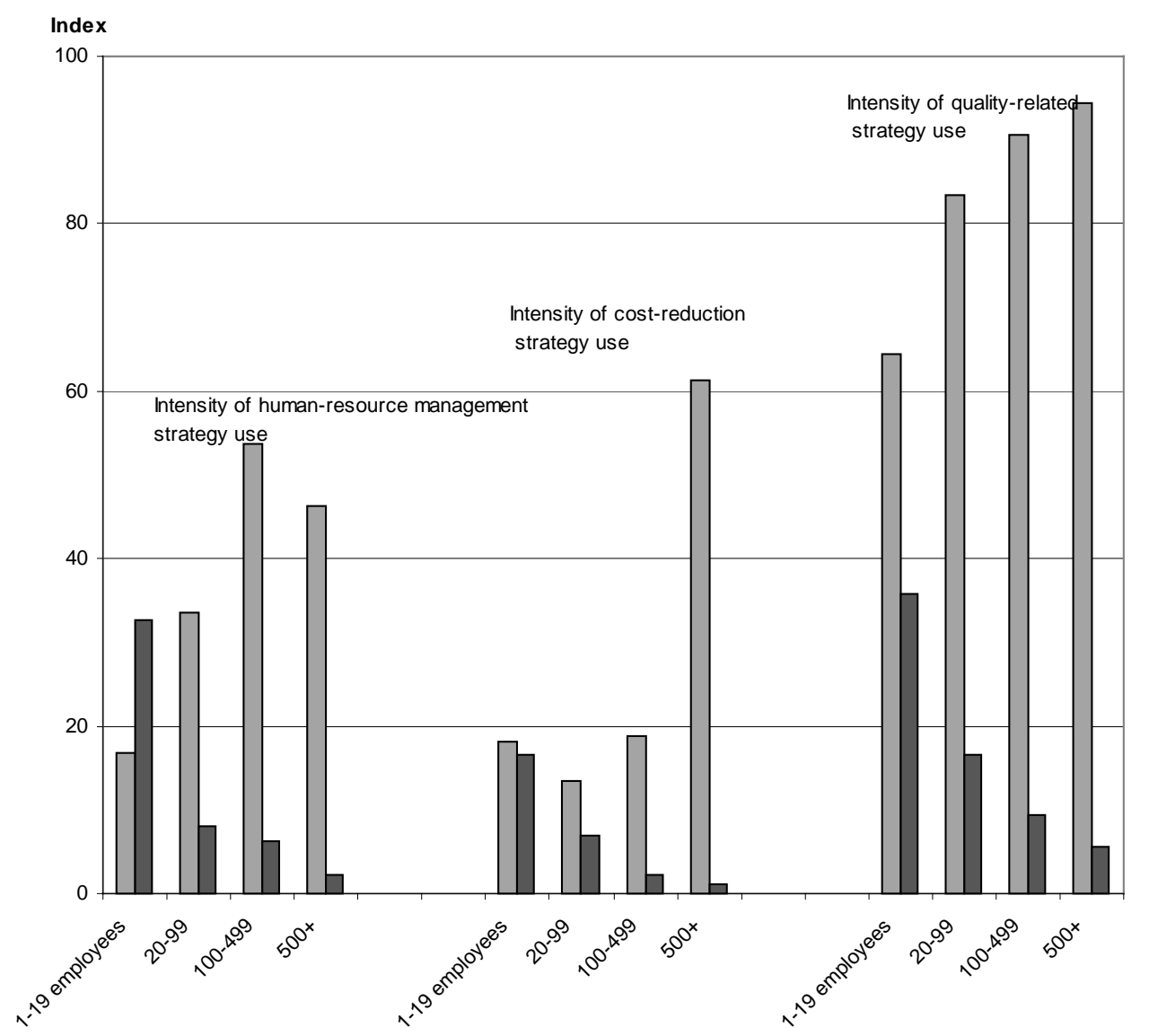

Note: These findings were based on a sample of 680 establishments and 1797 workers. For analytical purposes, business strategies were grouped under a few main classifications. In order to determine the relative importance of a cluster of business strategies, an index based on a range of scores for each classification of strategies was created. This involved assigning a value in a given range $(0-2,0-3$, or $0-5)$ to each business strategy in a particular cluster, based on the reported importance of the strategy in each establishment's overall business plan. Only two levels (HIGH and LOW) were measured for quality-related strategies compared with four each (HIGH, MEDIUM, LOW, and NONE) for human-resource management and cost-reduction strategies: Only HIGH and LOW indexes are shown in the figure. Source: Statistics Canada (1998). 
DSTI/DOC(2002)14

\section{ORGANISATIONAL CHANGE AND ICT INVESTMENTS}

There is a mutually beneficial relationship between organisational change in firms and ICT investments. Information technology is key to facilitating new organisational approaches, from lean production to teamwork to customer relations. On the other hand, organisational change is usually needed to realise the full benefits of information and communications technology. Complex technology requires flexible work organisation and, at the same time, it increases the capacity to adopt a flexible work organisation. In knowledge-based economies, managers need to understand both technological and organisational issues for the implementation of new business approaches.

Organisational approaches central to firm competitiveness are often enabled only by ICT investments. ICT permits closer interaction among internal functions such as production, marketing, finance and strategic decision making; higher levels of vertical integration and product diversification; more decentralisation and team-working; and closer interaction with customers and providers of intermediate goods and services. In Italy, one case study found that ICT permits economies of scale for batch production, enables internal restructuring by department and plant, strengthens market relations through electronic communication systems, and allows co-operative relationships and networking to be implemented through online communications systems (Antonelli and Marchionnatti, 1998). In Denmark, ICT investments enabled firms to produce with greater flexibility and shortened product cycles and to satisfy changing customer tastes and requirements (Table 14). A similar survey in Canada found that computer-based technology allowed significant organisational changes in the areas of re-engineering, decentralisation, part-time work and outsourcing (Table 15).

Conversely, ICT requires organisational changes in order to be implemented effectively. How ICT and workplace organisation are combined within a firm will determine the level of efficiencies achieved. In particular, enhanced communication, teamwork and training are needed to reap benefits from ICT investments. In a US business survey, the core skills needed by ICT managers were found to be nontechnical skills such as communication, problem-solving, analytical capacity and the ability to learn quickly $(I T A A, 2000)$. In Sweden, productivity increases in firms implementing new technology and having a flexible organisation were more than 50\% higher than in "non-flexible" workplaces (Nutek, 1999). In Denmark, firms that combined organisational changes with ICT evidenced far higher rates of innovation: $77 \%$ of firms reported new and improved products following ICT investments accompanied by changes to management structures and work organisation (Table 16).

In many cases, firm performance may not be improved if ICT investments are not accompanied by organisational changes. Lack of attention to human and organisational aspects can undermine ICT investments. A survey of UK firms found that $80-90 \%$ of ICT investments failed to meet all of their objectives due to poor human resource management and failure to involve users (Clegg et al., 1997). Similarly, firm performance in the Italian cotton textile industry was not improved when new information technologies were not accompanied by organisational changes (Antonelli and Marchionnatti, 1998). Studies of US firms show that the productivity effects of either organisational changes or ICT investments are small (Bresnahan et al., 1999). Studies also show that organisational changes are needed to accompany any investments in new processes, whether or not they are ICT-related (Brown, 2001). 
Table 14. Organisational change through ICT investments (Denmark)

\% of enterprises stating: "of high or moderate significance"

\begin{tabular}{lcc}
\hline & $\begin{array}{c}\text { As a motivating } \\
\text { factor }\end{array}$ & $\begin{array}{c}\text { As result of } \\
\text { investment }\end{array}$ \\
\hline Greater flexibility in production & & 81 \\
Production of new and improved products & 83 & 73 \\
Increased possibilities for meeting particular customer demands & 77 & 74 \\
Improved abilities for quality control and production process monitoring & 72 & 70 \\
Heightened prospects of entering into inter-enterprise networks & 74 & 29 \\
Labour cost savings & 16 & 76 \\
Savings in other costs (energy, material, inventory) & 82 & 67 \\
Shortening of production line & 73 & 80 \\
Enhanced production capacity & 82 & n.a. \\
Competitive advantages & 80 & n.a. \\
Employee motivation & 83 & 10 \\
Other & 55 & 12 \\
\hline
\end{tabular}

Source: Danish Ministry of Business and Industry (1996).

Table 15. Organisational change through ICT investments (Canada)

\begin{tabular}{|c|c|c|c|c|}
\hline & \multicolumn{4}{|c|}{ Percent of establishments that implemented: } \\
\hline & \multicolumn{2}{|c|}{ Computer-bassed technology } & \multicolumn{2}{|c|}{ Product or prcicess innovation } \\
\hline & No & Yes & No & Yes \\
\hline No change & 51.9 & 28.6 & 47.1 & 34 \\
\hline Downsizing & 16.5 & 14.4 & 18.0 & 7.9 \\
\hline Re-engineering & 14.0 & 25.8 & 16.1 & 24.9 \\
\hline Increased integration & 1.8 & 3.4 & 1.1 & 6.3 \\
\hline Increased centralisation & 0.4 & 1.0 & 0.6 & 0.5 \\
\hline Decreased centralisation & 0.3 & 0.7 & 0.2 & 1.1 \\
\hline Greater reliance on temporary workers & 1.8 & 1.4 & 1.4 & 2.1 \\
\hline Greater reliance on part-time workers & 1.5 & 5.3 & 2.9 & 2.6 \\
\hline Increase in overtime hours & 1.8 & 6.4 & 3.0 & 4.8 \\
\hline Adoption of flexible working hours & 5.0 & 0.6 & 3.2 & 4.2 \\
\hline Delayering & 0.0 & 0.1 & 0.1 & 0.0 \\
\hline Greater reliance on functional flexibility & 3.4 & 5.9 & 3.4 & 6.9 \\
\hline Increased reliance on external suppliers & 1.4 & 5.4 & 2.5 & 3.8 \\
\hline Increased inter-firm collaboration in R\&D & 0.4 & 1.2 & 0.6 & 1.0 \\
\hline
\end{tabular}

Source: Statistics Canada (1998). 
Table 16. ICT investments and organisational change (Denmark)

$\%$ of enterprises replying 'to a large or to some extent'

\begin{tabular}{lcccc}
\hline & $\begin{array}{c}\text { ICT/management } \\
\text { changes }\end{array}$ & Yes & $\begin{array}{c}\text { ICT/ } \\
\text { organisational } \\
\text { changes }\end{array}$ & No \\
& Yes & No & Yes & 76 \\
High flexibility in production process & 88 & 76 & 79 & 62 \\
Manufacturing of new or improved products & 77 & 69 & 78 & 76 \\
Compliance with specific customer demands & 81 & 72 & 76 & 76 \\
Savings in labour costs & 81 & & & \\
\hline Source: Danish Ministry of Business and Industry (1996) & & &
\end{tabular}

Source: Danish Ministry of Business and Industry (1996).

ICT investments as a share of GDP are higher in those countries which have more firms adopting new organisational approaches. The work practices which are generally associated with ICT use include: $i$ ) lean production which is made possible by ICT; ii) employee involvement schemes which build on the role of ICT in facilitating information flows; and iii) teamwork founded on ICT-based networks (Arnal et al., 2001) (Figure 4). Such investments are highest in Sweden and the United Kingdom and lowest in Portugal and Italy.

Figure 4. New work practices and ICT investment by country

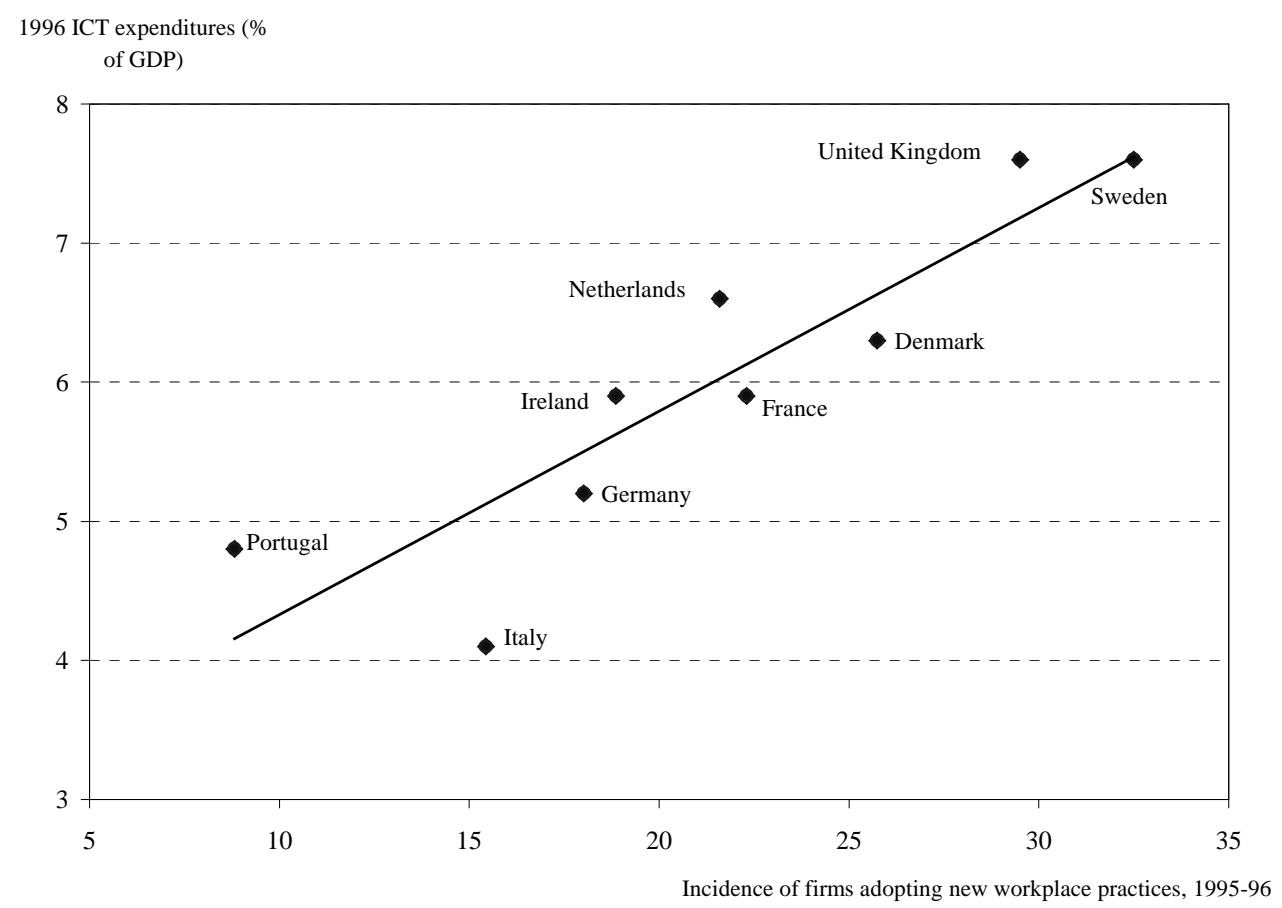

Source: Arnal et al. (2001). 
Some US evidence suggest that the mutually reinforcing effects of ICT and organisational change in terms of productivity growth can be seen in different industrial sectors. The banking and finance sector appears to be the sectoral leader world-wide in organisational change implementation coupled with ICT investments. In manufacturing, some industries appear to be reaping high productivity benefits from combined ICT and organisational investments. Ten US manufacturing industries were classified into four groups according to the use of new work practices and ICT-intensity. The average growth rate of labour productivity of firms with both high incidence of new work practices and ICT intensity at $7.8 \%$ outstripped growth rates in other industrial sectors with lower intensity of investments (Table 17). The productivity performance of manufacturing firms which have high ICT and do not adopt new work practices was poor.

Table 17. ICT investments, organisational change and productivity growth by sector

US manufacturing, average annual growth rate of labour productivity, 1992-98

\begin{tabular}{|c|c|c|}
\hline & High ICT intensity & Low ICT intensity \\
\hline High incidence of new work practices & $\begin{array}{l}\quad 7.8 \% \\
\text { Chemicals \& petroleum, machinery } \\
\text { \& instruments, transport equipment }\end{array}$ & $\begin{array}{c}1.4 \% \\
\text { Food \& tobacco, primary metals }\end{array}$ \\
\hline Low incidence of new work practices & $\begin{array}{c}0.5 \% \\
\text { Printing \& publishing, } \\
\text { miscellaneous manufactured } \\
\text { products }\end{array}$ & $\begin{array}{l}2.2 \% \\
\text { Textiles and apparel, pulp \& paper, } \\
\text { fabricated metals }\end{array}$ \\
\hline
\end{tabular}

Source: Arnal et al. (2001). 
DSTI/DOC(2002)14

\section{POLICIES FOR ORGANISATIONAL CHANGE}

Although it appears that most reorganisation efforts are carried out by firms without government assistance, governments can facilitate organisational change where it will enhance productivity. Given the important role played by ICT in current organisational change approaches, governments can ensure the provision of an infrastructure appropriate for ICT use. Regulatory conditions are needed which facilitate implementation of flexible work practices and constructive labour/management relations. Many reorganisation efforts fail because of inappropriate strategies, inefficient work practices and a lack of preparedness on the part of employers and employees. Governments can disseminate information on the benefits and types of organisational change, promote inter-firm co-operation, and link firms to sources of management training. More targeted approaches may be warranted for small firms or lagging industrial sectors to stimulate organisational change.

\section{Regulatory frameworks}

Labour market regulations should not hamper organisational change. Appropriate rules are needed regarding flexible job types, working hours, compensation, portable pensions, restructuring, etc., which safeguard the interests of both firms and workers. Measures to ease restrictions on labour mobility, both geographically and occupationally, can contribute to redressing skills imbalances and reduce the costs associated with organisational change. The portability of such job-related benefits as pensions can help make labour markets more flexible. Some countries are now allowing skilled retirees to re-enter the workforce without losing their pension rights.

Some recent OECD reforms have been moving in the right direction. In Korea, for example, 1998 amendments to the Labour Standards Act introduced a system for temporary work and employee leasing services. In 1999, Japan extended the range of eligible occupations for temporary work, leading to a surge in the numbers of temporary workers in Japan and enhancing flexibility for employers. In the Netherlands, a new Working Hours Act offers employers and employees greater flexibility within the limits of a consultative scheme, and the Dismissal Law Reform Bill provides for relaxation of the requirements for temporary contracts. As part of a regulatory reform programme, Portugal launched the Incentive System to Revitalise Business Modernisation (SIRME) including more flexible labour market provisions. Otherwise, in June 2001, the European Union set guidelines for regulating telework through collective agreements and stipulated that teleworkers should be employed on a similar basis to any other employee.

Labour unions can have an important influence on organisational changes within firms and have the potential for increasing worker participation and helping to implement new approaches such as teamwork $(O E C D, 2001 a)$. Evidence suggests that management-employee arrangements as embodied in work councils and which permit closer and less hierarchical contact between managers and employees can contribute to improved firm performance. Business outcomes can be enhanced by decentralising collective bargaining to enterprise or plant level $(O E C D, 1998)$. The presence of unions has also been found to raise the amount of training carried out by companies (OECD, 2001e). The role of unions in many countries is changing from being an advocate of regulations to include direct service provision, especially in the field of training. For example, the $2000 \mathrm{EU}$ summit in Lisbon produced a joint statement committing firms and unions to working together to advance ICT diffusion and training. 
However, changes in work practices -- particularly in areas such as performance-based pay systems, part-time work and telework, lean production and outsourcing -- are raising a number of challenges to traditional labour/management practices. Organisational change can lead to reduced security and changed benefits packages for employees as well as to lay-offs, particularly in the short term. For these reasons, unions can sometimes be resistant to certain organisational approaches. Unions need to be enlisted as partners in implementing organisational change in the interest of improved business performance. Constructive labour/management relations can facilitate the adoption of flexible work practices through more streamlined negotiations and by building a high-skill, high-trust enterprise climate. The link between institutions of worker representation and firm performance are sometimes controversial and require closer scrutiny (Arnal et al., 2001).

\section{Information dissemination}

One of the main inhibitors to organisational change is a lack of awareness and information on the part of firms and managers. Managers need information to, inter alia, assess new organisational approaches and ICT technologies in order to make informed decisions and adapt to the changing management role occasioned by organisational change. Facilitating managerial capacity to diagnose and interpret changes in the organisational environment is an important step before a re-organisation exercise is undertaken. Governments can play a role in the systematic collection and diffusion of information on market and technological developments along with information on best practice.

For example, the US Manufacturing Extension Partnership provides, among others services, information on business best practices for the selection and use of new technologies. The UK University for Industry manages the Learndirect Helpline, established in 1998, which answers questions and provides advice regarding new work practices and organisational approaches. In the Netherlands, Innovation Centres raise awareness among firms on the need for organisational change and provide them with access to business networks. New Zealand's BIZinfo provides information to businesses, including advice on organisational change, via 32 information centres, a toll-free number and a Web site. The European Commission's plan to create an eEurope depends heavily on information dissemination, skills training and workplace reorganisation (Box 5).

\section{Management training}

Studies show that the amount and content of management training can influence the performance and survival of firms, particularly smaller enterprises $(O E C D, 2001 f)$. Although organisational change is key to firm performance in dealing with new technologies and market competition, there is a lack of training in this area in most OECD countries especially with regard to small and medium-sized firms. Existing management courses often do not include organisational change as a subject for discussion. Courses specifically devoted to new work approaches are rare. A few governments are now implementing programmes specifically aimed at promoting organisational change in firms, including financial incentives, targeted advisory services and networking. For example, Ireland has initiated Operation On-Line to provide training modules through the Internet which are focused on e-business and enterprise skill development and targeted at micro enterprises.

Governments are supporting business networks which link firms and provide training and management advice. In the United Kingdom, the Business Link programme supports a number of network schemes, including Business Net and Business Bridge. The US Government supported a consortium of manufacturing firms called USNet to promote modernisation improvements and accompanying organisational change in small manufacturers. In Australia, the Business Networks Programme (BNP) 
assists firms in setting up networks to exchange information on management practices and other operational needs. The Networks Programme in New Zealand also included organisational change among its topics. The System to Realise Dynamic Networked Organisations in the Consultancy/Agency Business (DYNOCA) is a European Commission project to develop organisational models and related software.

\section{Box 5: Creating eEurope}

The eEurope initiative was launched in December 1999 by the European Commission to bring the benefits of the Information Society to all Europeans. The key objectives of eEurope are to: $i$ ) bring every citizen, home and school, every business and administration, into the digital age and on line; ii) create a digitally literate Europe, supported by an entrepreneurial culture ready to finance and develop new ideas; and iii) ensure that the whole process is socially inclusive, builds consumer trust and strengthens social cohesion.

The subsequent eEurope 2002 Action Plan, agreed by Heads of State and Government in Feira in June 2000, sets out a roadmap to achieve eEurope's targets. The three objectives are:

1. A cheaper, faster, secure Internet (cheaper and faster Internet access; faster Internet for researchers and students; secure networks and smart cards).

2. Investing in people and skills (taking European youth into the digital age; working in the knowledgebased economy; participation for all in the knowledge-based economy).

3. Stimulate the use of the Internet (accelerating e-commerce; government on line, i.e electronic access to public services; health on line; European digital content for global networks; and intelligent transport systems).

Each of the subheadings has several targets, which are regularly monitored and benchmarked. For example, the targets under item "working in the knowledge-based economy" in objective 2 are:

- Support greater flexibility in the workplace, e.g. teleworking and part-time working, where appropriate through agreements by Social Partners and backed up by Member States.

- Promote a network of learning and training centres for demand-driven information and communications technology training and retraining of postgraduates.

- Set up public Internet access points in public spaces and establish multimedia tele-centres in all communities providing access to training and e-work facilities, where appropriate using the Structural Funds. Give the labour force the chance to become digitally literate through life-long learning;

- Significantly increase information technology training places and courses and promote gender equality in such courses (both in work and in educational institutions), using European Social funds where appropriate;

- Establish a European diploma for basic information technology skills, with decentralised certification procedures.

Source: European Commission (http://europa.eu.int/information_society/eeurope/action_plan/index_en.htm). 
Governments are also promoting partnerships between universities, public research bodies and firms to exchange advice and information on organisational change. Denmark has recently initiated a Management, Organisation and Competence programme providing matching funds to public/private partnerships aimed at promoting organisational change in firms (Box 6). In the United Kingdom, the Teaching Company Scheme (TCS) supports partnerships between firms and universities for training in advanced business practices. TCS partnerships are financed by government grants made to the university partner, complemented by financial contributions by the partner firm. These funds support the employment of Teaching Company Associates (TCA) who work with the company partner to improve services and processes.

\section{Box 6. Supporting organisational change in Denmark}

The Danish Government is giving financial incentives to organisational change in firms under its Management, Organisation and Competence project. Regional Change Contracts are concluded between public institutions and businesses that wish to develop their organisation or introduce new management models. The central government finances up to $50 \%$ of the costs incurred for the public institutions entering into a co-operation contract to advise on firm-level organisational changes. The programme offers improved access to counselling, one-stop-shops for inservice training, a forum for research in management and organisation, and local joint ventures for the development of management and firm organisation. Denmark also established a Management Centre to create a dialogue and mediate knowledge on management methods and values. The Centre will be a focus for business, scientists, and consultants working with business and management development. The potential of new management models is documented and policy tools adapted, especially for small business. One of its objectives is to develop an indicator to measure a firm's capability with respect to worker satisfaction, customer satisfaction, leadership, staff management and handling of core processes. 


\section{REFERENCES}

ANTONELLI, C. and R. MARCHIONATTI (1998), "Technological and Organisational Change in a Process of Industrial Rejuvenation: The Case of the Italian Cotton Textile Industry", Cambridge Journal of Economics, Vol. 22.

APPELBAUM, E. and R. BATTS (1994), The New American Workplace: Transforming Work Systems in the United States, ILR Press, New York.

ARNAL, E., O. WOOSEK, and R. TORRES (2001), Knowledge, Work Organisation and Economic Growth, OECD Labour Market and Social Policy Occasional Papers No.50 [DEELSA/ELSA/WD(2001)3].

BENSON, J. and N. IERONIMO (1996), "Outsourcing Decisions: Evidence from Australia-Based Enterprises", International Labour Review, 135 (1).

BLACK, S.E. and L.M. LYNCH (1996), "Human Capital Investments and Productivity", American Economic Review.

BLACK, S.E. and L.M. LYNCH (1997), How to Compete: The Impact of Workplace Practices and Information Technology on Productivity, NBER Working Paper 6120.

BLACK, S.E. and L.M. LYNCH (2000), What's Driving the New Economy: The Benefits of Workplace Innovation, NBER Working Paper 7479.

BRESNAHAN, T.F., E. BRYNJOLFSSON and L.M. HITT (1999), Information Technology, Workplace Organization and the Demand for Skilled Labour: Firm-Level Evidence, NBER Working Paper 7136.

BROWN, S. (2001), "Managing Process Technology: Further Empirical Evidence from Manufacturing Plants", Technovation 21.

BRYSON, A. (1999), The Impact of Employee Involvement on Small Firms' Financial Performance, NIESR, United Kingdom.

CAMPBELL, J. R. and J.D.M. FISHER (1998), Organizational Flexibility and Employment Dynamics at Young and Old Plants, NBER Working Paper 6809.

CAPELLI, P. and D. NEUMARK, (1999), Do "High Performance” Work Practices Improve Establishment-level Outcomes? NBER Working Paper 7374.

CAPGEMINI (2000), Journal of the Cap Gemini Applied Knowledge Management Team.

CARAYANNIS, E. and J. SAGI (2001), "New vs. Old Economy: Insights on Competitiveness in the Global IT Industry", Technovation 21. 
CASTLEY, R. J. (1995), New Industrial Organisation and New Technologies: Implications for Labour, Skills and Training in Developing Countries, Institute for Development Policy and Management Discussion Paper No.39, University of Manchester.

CEDEFOP (1997), Key Data on Vocational Training in the European Union, European Centre for the Development of Vocational Training.

CLEGG, C., C. AXTELL, L. DAMODARANT, B. FARBEY, R. HULL, R. LLOYD-JONES, J. NICHOLLS, R. SELLS, and C. TOMLINSON (1997), "Information Technology: A Study of Performance and the Role of Human and Organisational Factors", Ergonomics, Vol. 40:9.

COMMISSION OF THE EUROPEAN COMMUNITIES (2000), Benchmarking Diffusion of Information and Communication Technologies (ICT) and New Organisational Arrangements $(O)$, Final Report 2000.

DANISH MINISTRY OF BUSINESS AND INDUSTRY (1996), Technological and Organisational Change: Implications for Labour Demand, Enterprise Performance and Industrial Policy, Country Report Denmark.

DOYLE, G. M. (2000), Making Networks Work: A Study of Best Practice in Business-led Networks and the Lessons for Ireland from Abroad, A Skillnets Report.

EUROPEAN FOUNDATION FOR THE IMPROVEMENT OF LIVING AND WORKING CONDITIONS (1997), New Forms of Work Organisation: Can Europe Realise its Potential?, Survey of Employee Direct Participation in Organisational Change (EPOC).

FINEGOLD, D. and K. WAGNER (1998), "The Search for Flexibility: Skills and Workplace Innovation in the German Pump Industry", British Journal of Industrial Relations.

GELLATLY, G. (1999), Differences in Innovator and non-Innovator Profiles: Small Establishments in Business Services, Statistics Canada Paper no. 143.

HUSELID, M.A. and B.E. BECKER (1996), "High Performance Work Systems and Firm Performance: Cross Sectional vs Panel Results", Industrial Relations, Vol. 35.

ICHNIOWSKI, C. (1990), Human Resource Management Systems and the Performance of U.S. Manufacturing Businesses, NBER Working Paper 3449.

INFORMATION TECHNOLOGY ASSOCIATION OF AMERICA (ITAA) (2000), Bridging the Gap: Information Technology Skills for a New Millenium.

JARREL, S.L. and G.S. EASTON (1996), "An Exploratory Empirical Investigation of the Effects of Total Quality Management on Corporate Performance", in The Practice of Quality Management, P. Lederer (ed.), Harvard University Press, Boston.

KHAN, M.R.T. (2000), "Business Process Reengineering of an Air Cargo Handling Process", International Journal of Production Economics, 63.

KLING, J. (1995), "High Performance Work Systems and Firm Performance", Monthly Labor Review, May. 
KÖHLER, C. and J. WOODWARD (1997), "Systems of Work and Socio-Technical Structures: A Comparison of Germany, Spain, France and Japan", European Journal of Industrial Relations, Vol 3: 1 .

KRUGER, D. and I. FUYUNO (2001), "Job Flexibility in Japan", Far Eastern Economic Review, 8 February.

LAWLER, E., S.A. MOHRMAN and G.E. LEDFORD (1998), Strategies for High Performance Organizations - the CEO Report: Employee Involvement, TQM and Reengineering Programs in Fortune 1000 Corporations, Jossey-Bass, San Francisco.

LEE, J., J. LEE and W.E. SOUDER (2000), "Differences of Organisational Characteristics in New Product Development: Cross Cultural Comparison of Korea and the US", Technovation 20.

LOCKAMY III, A. and W. SMITH (1997) "A Strategic Alignment Approach for Effective Business Process Reengineering: Linking Strategy, Processes and Customers for Competitive Advantage", International Journal of Production Economics 50.

MAGUN, S. (1998), Restructuring in Canadian Industries: A Micro-Analysis, Industry Canada Working Paper No. 23.

MAVRINAC, S. and T. SIESFELD (1998), "Measures that Matter: An Exploratory Investigation of Investors' Information Needs and Value Priorities", in Enterprise Value in the Knowledge Economy: Measuring Performance in the Age of Intangibles, OECD and Ernst \& Young Center for Business innovation.

MEISTER, J.C. (1998), "Extending the Short Shelf Life of Knowledge", Training and Development, June.

MONGA, R.C. (2000), Managing Enterprise Productivity and Competitiveness, ILO Working Paper PMD-3.

NUTEK (1996), Towards Flexible Organisations, Stockholm.

NUTEK (1999), Flexibility Matters - Flexible Enterprises in the Nordic Countries, Stockholm.

OECD (1998), "High-Performance Workplaces and Intangible Investment", Technology, Productivity and Job Creation: Best Policy Practices.

OECD (2001a), The New Economy: Beyond the Hype: Final Report of the OECD Growth Project.

OECD (2001b), Knowledge Management: Learning-By-Comparing Experiences from Private Firms and Public Organisations (Internal Working document).

OECD (2001c), Human Resources in the New Economy: Challenges and Opportunities for Education and Training [PAC/AFF/LMP(2000)13].

OECD (2001d), Main Results from the NIS Focus Groups (Internal Working document).

OECD (2001e), Firms, Workers and the Changing Workplace: Considerations from the Old and the New Economy [PAC/AFF/LMP(2001)13].

OECD(2001f), Management Training for SMEs (Internal OECD document). 
DSTI/DOC(2002)14

PRICEWATERHOUSECOOPERS (1999), Business Process Outsourcing: Strategic Development of Internationally Traded Service Industries throughout Ireland, Report commissioned by Enterprise Ireland.

PROGRESSIVE POLICY INSTITUTE (2000), New Economy Index, Washington, D.C.

SESSI (2001), L'Industrie Française, Edition 2000-2001.

SOHAL, A.S., J. GORDON, G. FULLER and A. SIMON (1999), "Manufacturing Practices and Competitive Capability: An Australian Study", Technovation 19.

STATISTICS CANADA (1998), The Evolving Workplace: Findings from the Pilot Workplace and Employee Survey (WES).

TSUJI, Y.S. (2001), "Product Development in the Japanese and US Printer Industries", Technovation 21.

ZELL, D. (1997), Changing by Design - Organizational Innovation at Hewlett-Packard, ILR Press, New York.

WOMACK, J. and D. ROOS (1990) The Machine that Changed the World, New York. 